\title{
Relationships between bottom water carbonate saturation and element/Ca ratios in coretop samples of the benthic foraminifera Oridorsalis umbonatus
}

\author{
C. F. Dawber ${ }^{1}$ and A. Tripati ${ }^{1,2}$ \\ ${ }^{1}$ Department of Earth Sciences, University of Cambridge, Downing Street, Cambridge, CB1 2EQ, UK \\ ${ }^{2}$ Departments of Atmospheric and Oceanic Sciences and Earth and Space Sciences, Institute of Geophysics and Planetary \\ Physics, Institute of the Environment and Sustainability, University of California, Los Angeles, USA \\ Correspondence to: C. F. Dawber (dawber.caroline@gmail.com) and A. Tripati (ripple@zephyr.ess.ucla.edu)
}

Received: 15 September 2011 - Published in Biogeosciences Discuss.: 2 February 2012

Revised: 12 June 2012 - Accepted: 21 June 2012 - Published: 9 August 2012

\begin{abstract}
Elemental ratios in benthic foraminifera have been used to reconstruct bottom water temperature and carbonate saturation $\left(\Delta\left[\mathrm{CO}_{3}^{2-}\right]\right)$. We present elemental data for the long-ranging benthic foraminifera Oridorsalis umbonatus from sediment core tops that span a narrow range of temperatures and a wide range of saturation states. $\mathrm{B} / \mathrm{Ca}, \mathrm{Li} / \mathrm{Ca}, \mathrm{Sr} / \mathrm{Ca}$ and $\mathrm{Mg} / \mathrm{Ca}$ ratios exhibit positive correlations with bottom water carbonate saturation. The sensitivity of individual element/calcium ratios to bottom water $\Delta\left[\mathrm{CO}_{3}^{2-}\right]$ varies considerably, with $\mathrm{B} / \mathrm{Ca}$ being most sensitive and $\mathrm{Sr} / \mathrm{Ca}$ the least sensitive. The empirically derived sensitivity of $\mathrm{B} / \mathrm{Ca}, \mathrm{Li} / \mathrm{Ca}, \mathrm{Mg} / \mathrm{Ca}$ and $\mathrm{Sr} / \mathrm{Ca}$ to bottom water $\Delta\left[\mathrm{CO}_{3}^{2-}\right]$ are $0.433 \pm 0.053$ and $0.0561 \pm 0.0084 \mu \mathrm{mol} \mathrm{mol}^{-1} \mu \mathrm{mol} \mathrm{kg}{ }^{-1}$ and $0.0164 \pm 0.0015$ and $0.00241 \pm 0.0004 \mathrm{mmol} \mathrm{mol}^{-1} \mu \mathrm{mol} \mathrm{kg}{ }^{-1}$, respectively. To assess the fidelity of these relationships and the possibility of applying these relationships to earlier periods of Earth history, we examine the mechanisms governing elemental incorporation into foraminiferal calcite. Empirical partition coefficients for $\mathrm{Li}$ and $\mathrm{Sr}$ are consistent with Rayleigh fractionation from an internal pool used for calcification. For $O$. umbonatus and other benthic species, we show that the fraction of $\mathrm{Ca}$ remaining in the pool is a function of bottom water $\Delta\left[\mathrm{CO}_{3}^{2-}\right]$, and can be explained by either a growth rate effect and/or the energetic cost of raising vesicle $\mathrm{pH}$ at the site of calcification. Empirical partition coefficients for $\mathrm{Mg}$ and B may also be controlled by Rayleigh fractionation, but require that either the fractionation factor from the internal pool is smaller than the inorganic partition coefficient and/or
\end{abstract}

additional fractionation mechanisms. $O$. umbonatus element ratio data may also be consistent with fractionation according to the surface entrapment model and/or the presence of discrete high- and low-Mg calcite phases. However, at present we are limited in our ability to assess these mechanisms. The new $\mathrm{X} / \mathrm{Ca}$ data for $O$. umbonatus provide constraints to test the role of these mechanisms in the future.

\section{Introduction}

Elemental ratios in benthic foraminifera can be routinely measured with excellent precision, and have been used for several decades to investigate past variations in seawater composition and hydrographic parameters (e.g. Lear et al., 2000, 2003, 2010; Rosenthal et al., 1997, 2006; Marchitto et al., 2002, 2007; Tripati et al., 2005; Tripati and Elderfield, 2005; Elderfield et al., 2006; Yu and Elderfield, 2007, 2008; Bryan and Marchitto, 2008; Dawber and Tripati, 2011a). However, the mechanisms of cation incorporation into foraminiferal calcite and the nature of relationship with hydrographic parameters and seawater chemistry are not well understood and are an area of active research. A number of empirical-based studies have demonstrated that elemental ratios $(\mathrm{X} / \mathrm{Ca})$ in benthic foraminifera (e.g. $\mathrm{Sr} / \mathrm{Ca}$, $\mathrm{Li} / \mathrm{Ca}$ and $\mathrm{B} / \mathrm{Ca}$ ) correlate with bottom water carbonate saturation $\left(\Delta\left[\mathrm{CO}_{3}^{2-}\right]\right.$, where $\Delta\left[\mathrm{CO}_{3}^{2-}\right]$ is the difference between saturation and in situ $\left[\mathrm{CO}_{3}^{2-}\right]$ (Lear and Rosenthal, 2006; Yu and Elderfield, 2007, 2008; Dissard et al., 2010), 
but the basis for the relationship is unknown. Culture studies on two species of planktonic foraminifera report similar relationships between $\mathrm{Sr} / \mathrm{Ca}$ and $\mathrm{U} / \mathrm{Ca}$ and ambient $\mathrm{pH}$ and/or $\left[\mathrm{CO}_{3}^{2-}\right]$, and hypothesize that the relationship reflects a kinetic influence of carbonate chemistry on calcification rate (Lea et al., 1999; Russell et al., 2004). Inorganic calcite precipitation and foraminifera culturing experiments provide clues to the nature of the relationship between foraminifera $\mathrm{X} / \mathrm{Ca}$ and $\Delta\left[\mathrm{CO}_{3}^{2-}\right]$, but at present it is not known which mechanism(s) exerts the dominant influence.

Precipitation experiments report multiple influences on cation $\left(\mathrm{Sr}^{2+}, \mathrm{Mn}^{2+}, \mathrm{Cd}^{2+}, \mathrm{Mg}^{2+}, \mathrm{Co}^{2+}\right)$ incorporation in inorganic calcite (and aragonite), including precipitation rate, temperature and solution, and solid composition (e.g. Holland et al., 1964; Lorens, 1981; Mucci and Morse, 1983; Morse and Bender, 1990; Rimstidt et al., 1998; Nehrke et al., 2007; Tang et al., 2008). The "surface entrapment model" for inorganic calcite precipitation (Watson and Liang, 1995; Watson, 2004; Gabitov and Watson, 2006) has been shown to be consistent with experimental data and provides a viable mechanism for the apparent dependency of Sr partition coefficients on precipitation rate, solution chemistry, temperature and $\mathrm{pH}$ (Lorens, 1981; Gabitov and Watson, 2006; Tang et al., 2008). This model proposes that during inorganic calcite precipitation a transitional surface layer is formed, which may be enriched in $\mathrm{Sr}$ (or other ions) due to disequilibrium partitioning. Two kinetic effects are thought to cause this disequilibrium partitioning (Tang et al., 2008): (1) crystal growth behaviour, i.e., at faster precipitation rates, more $\mathrm{Sr}$ is trapped in the surface layer and (2) ion diffusion behaviour, i.e., Sr diffuses back into the surface layer prior to being incorporated into the crystal lattice. The Sr enrichment in the surface layer relative to the crystal interior constitutes an effective partition coefficient, which has been suggested to be a function of temperature (through the dependency on diffusivity), growth rate and/or surface composition (Watson, 2004), and solution chemistry (e.g., pH and ionic strength, though the dependency of surface cation adsorption, Tang et al., 2008). The surface entrapment model may also be relevant to other cations, although the magnitude of effective partition coefficient will likely vary between cations to reflect differences in diffusivity and surface adsorption properties.

Empirical partition coefficients for benthic foraminifera $\left(D_{X}\right)$ are notably different to experimentally derived partition coefficients for inorganic calcite $(\alpha$; e.g. Elderfield et al., 1996). Inorganic partition coefficients are a function of precipitation rate, tending away from $\alpha$, towards 1, at faster rates (Lorens, 1981; Pingitore and Eastman, 1986; Rimstidt et al., 1998). Sr partition coefficients in cultured planktonic foraminifera $\left(D_{\mathrm{Sr}}<1\right)$ increase with increased calcification rate (Kisakürek et al., 2008). In contrast, the opposite relationship is observed between $D_{\mathrm{Sr}}$ and calcification rate in cultured benthic foraminifera (Erez, 2003). These observations imply that inorganic calcite precipitation is probably an overly simplistic model of foraminifera calcification, which is likely mediated by additional kinetic and/or physiological processes.

Perforate foraminifera are thought to biomineralize through the vacuolization of seawater, which is modified through physiological reactions to increase the $\mathrm{pH}$ (and hence $\left[\mathrm{CO}_{3}^{2-}\right]$ ), and perhaps reduce $\mathrm{Mg}$ poisoning (Erez et al., 1994; Erez, 2003; de Nooijer et al., 2009). The $\left[\mathrm{Ca}^{2+}\right] /\left[\mathrm{CO}_{3}^{2-}\right]$ of the seawater vacuole may directly influence $D_{X}$ in a similar manner to inorganic calcite (Nehrke et al., 2007). If so, the physiological reactions that increase the vacuole $\mathrm{pH}$ (and $\left[\mathrm{CO}_{3}^{2-}\right]$ ) may account for the speciesspecific sensitivities of X/Ca to bottom water $\Delta\left[\mathrm{CO}_{3}^{2-}\right]$ (Hall and Chan, 2004; Lear and Rosenthal, 2006; Yu and Elderfield, 2007).

An alternative empirical model that is supported by experimental observations proposes that the $D_{X}$ in foraminifera and other biogenic carbonates are a function of the amount of Ca remaining in the "internal biomineralization pool" after the precipitation of $\mathrm{CaCO}_{3}$ (Rayleigh fractionation; Elderfield et al., 1996; Erez, 2003; Gagnon et al., 2007). If the fraction of calcium remaining in this internal pool is influenced by $\left[\mathrm{CO}_{3}^{2-}\right]$ and/or $\Delta\left[\mathrm{CO}_{3}^{2-}\right]$, then the Rayleigh fractionation model may be a valid mechanism to relate foraminifera $\mathrm{X} / \mathrm{Ca}$ to bottom water $\Delta\left[\mathrm{CO}_{3}^{2-}\right]$. Variations in the fraction of calcium utilized may arise from changes in either the calcification rate, the size of the biomineralisation reservoir, or the flushing/replenishing time of the pool. The flushing rate may be directly linked to the calcification rate, as the faster the rate of $\mathrm{CaCO}_{3}$ precipitation, the quicker the reservoir may need to be replenished (Elderfield et al., 1996; Erez, 2003).

Recent in vivo experiments of foraminiferal calcification (Bentov and Erez, 2005) observed the precipitation of two types of calcite in perforate foraminifera, a "high-Mg" primary layer sandwiched between thick (90\% of test) "low$\mathrm{Mg}$ "secondary layers (not to be confused with diagenetic inorganic calcite). The concentration of $\mathrm{Mg}, \mathrm{S}$ and possibly other trace metals differs between high- and low-Mg calcite (Erez, 2003), and the observed inter-test heterogeneity of some trace metals (Szafranek and Erez, 1993; Eggins et al., 2004; Anand and Elderfield, 2005; Sadekov et al., 2005; Kunioka et al., 2006) is consistent with the presence of distinct types of calcite in foraminiferal tests. High Mg calcite is more soluble than low-Mg calcite (Morse and Mackenzie, 1990), and therefore the proportion of primary ("high-Mg") to secondary ("low-Mg") calcite in foraminiferal tests may be controlled by ambient $\Delta\left[\mathrm{CO}_{3}^{2-}\right]$. If trace metal concentrations in high- and low-Mg calcite are shown to be different, variations in the proportions of primary and secondary calcite may provide another viable mechanism for relating foraminiferal $\mathrm{X} / \mathrm{Ca}$ to bottom water $\Delta\left[\mathrm{CO}_{3}^{2-}\right]$.

Here we employ an empirical approach to investigate the sensitivity of elemental ratios $(\mathrm{B} / \mathrm{Ca}, \mathrm{Li} / \mathrm{Ca}, \mathrm{Sr} / \mathrm{Ca}$ and $\mathrm{Mg} / \mathrm{Ca}$ ) in core top specimens of the benthic foraminifera $O$. umbonatus to bottom water $\Delta\left[\mathrm{CO}_{3}^{2-}\right]$. We assess the 
Table 1. Location details of core top samples used in this study.

\begin{tabular}{|c|c|c|c|c|c|}
\hline Core & Depth & Basin & $\begin{array}{r}\text { Latitude } \\
{ }^{\circ} \mathrm{N}\end{array}$ & $\begin{array}{r}\text { Longitude } \\
{ }^{\circ} \mathrm{W}\end{array}$ & $\begin{array}{r}\text { Water depth } \\
\mathrm{m}\end{array}$ \\
\hline BOFS $5 \mathrm{~K}$ & core top & Atlantic Ocean & 50.70 & 21.90 & 3547 \\
\hline BOFS $8 \mathrm{~K}$ & core top & Atlantic Ocean & 52.50 & 22.10 & 4045 \\
\hline CD 113A SITE A & core top & Atlantic Ocean & 52.92 & 16.92 & 3600 \\
\hline NEAP 17B & core top & Atlantic Ocean & 56.10 & 27.20 & 2734 \\
\hline NEAP 19B & core top & Atlantic Ocean & 52.45 & 30.20 & 3283 \\
\hline NEAP 20B & core top & Atlantic Ocean & 42.29 & 28.24 & 2878 \\
\hline T86 15B & core top & Atlantic Ocean & 30.48 & 36.95 & 3271 \\
\hline T86 5B & core top & Atlantic Ocean & 46.90 & 25.40 & 3121 \\
\hline T88 11B & core top & Atlantic Ocean & 45.40 & 25.40 & 2741 \\
\hline T88 12B & core top & Atlantic Ocean & 44.10 & 24.90 & 3052 \\
\hline T88 15AB & core top & Atlantic Ocean & 38.90 & 25.00 & 2738 \\
\hline T88 17B & core top & Atlantic Ocean & 35.40 & 29.40 & 2934 \\
\hline T88 19B & core top & Atlantic Ocean & 31.31 & 30.48 & 3726 \\
\hline T90 10B & core top & Atlantic Ocean & 45.36 & 27.15 & 2162 \\
\hline T90 13B & core top & Atlantic Ocean & 44.00 & 20.02 & 4016 \\
\hline T90 15B & core top & Atlantic Ocean & 47.60 & 20.92 & 4177 \\
\hline Т90 2B & core top & Atlantic Ocean & 53.10 & 20.80 & 2731 \\
\hline T90 4B & core top & Atlantic Ocean & 47.20 & 21.39 & 3945 \\
\hline T90 7B & core top & Atlantic Ocean & 46.30 & 23.61 & 3752 \\
\hline T90 8B & core top & Atlantic Ocean & 46.20 & 23.72 & 3393 \\
\hline T90 11B & core top & Atlantic Ocean & 45.00 & 24.66 & 3208 \\
\hline WIND 10B & core top & Indian Ocean & -29.12 & -47.55 & 2871 \\
\hline WIND 1B & core top & Indian Ocean & -35.12 & -35.54 & 4156 \\
\hline WIND 3B & core top & Indian Ocean & -32.64 & -48.49 & 3731 \\
\hline WIND 5B & core top & Indian Ocean & -31.57 & -47.57 & 3684 \\
\hline $1123 \mathrm{C} 1-1$ & $3-5 \mathrm{~cm}$ & Pacific Ocean & -0.02 & -161.02 & 3411 \\
\hline $2.5 \mathrm{BC} 37$ & core top & Pacific Ocean & 0.00 & -159.48 & 2445 \\
\hline $1.5 \mathrm{BC} 33$ & core top & Pacific Ocean & -1.00 & -157.85 & 2015 \\
\hline 2BC13 & core top & Pacific Ocean & 0.01 & -158.91 & 2301 \\
\hline 4BC51 & core top & Pacific Ocean & -0.02 & -161.02 & 3411 \\
\hline $5.5 \mathrm{BC} 58$ & core top & Pacific Ocean & -0.01 & -162.22 & 4341 \\
\hline 1BC3 & core top & Pacific Ocean & -2.24 & -157.00 & 1616 \\
\hline
\end{tabular}

fidelity of these relationships by examining the consistency of the $\mathrm{X} / \mathrm{Ca}$ data and partition coefficients with the hypothesized biomineralziation models discussed. $O$. umbonatus was chosen for this study because it is a shallow-dwelling infaunal species that is commonly found in marine sediments dating back to the late Cretaceous (Corliss 1985; Lear et al., 2000) and therefore is widely used for "deep-time" paleoceanographic reconstructions (e.g., Lear et al., 2000; Tripati et al., 2005; Tripati and Elderfield, 2005; Dawber et al., 2011a). Better understanding of the systematics of the relationship between $O$. umbonatus $\mathrm{X} / \mathrm{Ca}$ and bottom water $\Delta\left[\mathrm{CO}_{3}^{2-}\right]$ will allow for greater confidence in applying these proxies to study earlier periods of Earth's history.

\section{Materials and methods}

Coretop samples were chosen from the Atlantic, Pacific and Indian Oceans (Table 1, Fig. 1) to span a large range of bottom water carbonate saturation ( -23 to $44 \mu \mathrm{mol} \mathrm{kg}-1$ ) and a narrow temperature range $\left(1.1-3.6^{\circ} \mathrm{C}\right)$. Hydrographic data were obtained from the CARINA and GLODAP datasets using ocean data viewer (ODV). Post-industrial carbonate system parameters were calculated in ODV using constants from the Best Practices Handbook (Dickson et al., 2007). Pre-industrial carbonate system parameters were calculated using anthropogenic corrected estimates of DIC in CO2SYS, using the set of constants from Mehrbach et al. (1973) as refit by Dickson and Millero (1987) and the $\mathrm{K}_{\mathrm{HSO} 4}$ formulation of Dickson (1990).

Specimens of $O$. umbonatus were picked from the $>150 \mu \mathrm{m}$ size fraction and cleaned using a standard oxidative-cleaning protocol (Barker et al., 2003). X/Ca ratios were determined from matrix-matched intensity ratios on a quadrapole inductively coupled plasma mass spectrometer at the University of Cambridge Yu et al. (2005) and Tripati et al. (2009). Samples were screened for contaminating phases including clays, ferromanganese oxides and 


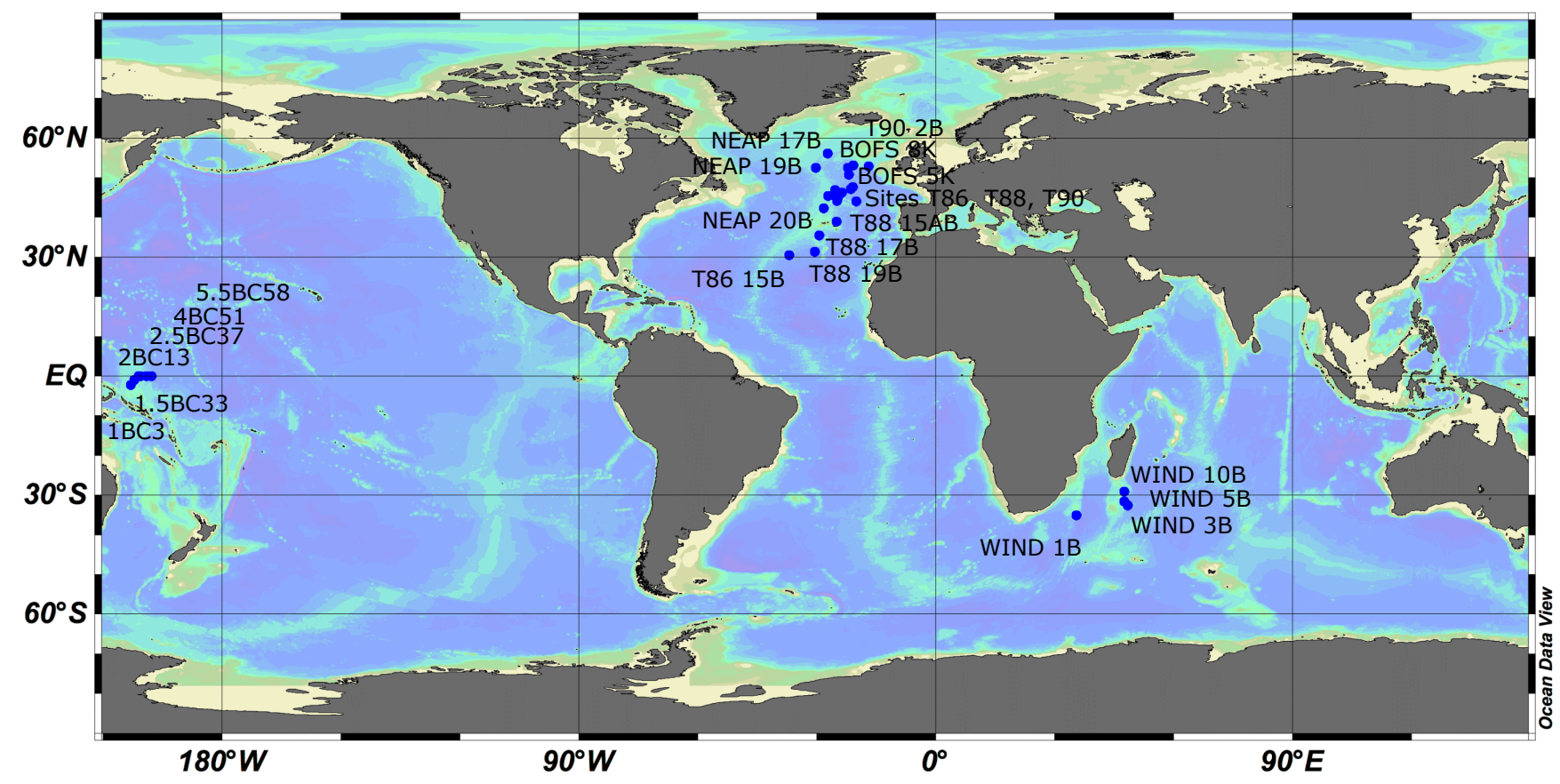

Fig. 1. Map of core locations. For clarity, not all locations are annotated. For the full list refer to Table 1.

carbonates, organic matter and silicates using ancillary $\mathrm{X} / \mathrm{Ca}$ ratios (i.e., $\mathrm{Al} / \mathrm{Ca}, \mathrm{Fe} / \mathrm{Ca}, \mathrm{Si} / \mathrm{Ca}, \mathrm{Mn} / \mathrm{Ca}$ ). Any samples that fell outside the range reported by Barker et al. (2003) were excluded (e.g. $\mathrm{Fe} / \mathrm{Mg}$ ratios of $>0.1 \mathrm{~mol} \mathrm{~mol}^{-1}$ ). We routinely achieved the analytical accuracy and precision on the $\mathrm{X} / \mathrm{Ca}$ ratios reported by $\mathrm{Yu}$ et al. (2005). Typical reproducibility of our method based on benthic foraminiferal replicate samples is better than $1.6 \%$ for $\mathrm{Mg} / \mathrm{Ca}, \mathrm{B} / \mathrm{Ca}$ and $\mathrm{Li} / \mathrm{Ca}$, and better than $0.7 \%$ for $\mathrm{Sr} / \mathrm{Ca}$ (\% relative standard deviation)

We also compiled published data on $\mathrm{X} / \mathrm{Ca}$ ratios in $O$. umbonatus from the literature and calculated bottom water saturation at these sites using the same hydrographic datasets and constants mentioned above. We compare measured X/Ca ratios to all published data for $O$. umbonatus available, with a single exception. We exclude comparisons to Rathmann et al. (2004) and Rathmann and Kuhnert (2008) simply because they used laser ablation techniques to determine $\mathrm{X} / \mathrm{Ca}$ ratios, and it is unclear how representative values that are measured using this method are of whole test composition.

Foraminiferal partition coefficients are calculated using measured foraminifera $\mathrm{X} / \mathrm{Ca}$ and the $\mathrm{X} / \mathrm{Ca}$ of seawater $\left(\mathrm{Mg} / \mathrm{Ca} \sim 5.3 \mathrm{~mol} \mathrm{~mol}^{-1} ; \mathrm{B} / \mathrm{Ca} \sim 0.040 \mathrm{~mol} \mathrm{~mol}^{-1} ; \mathrm{Li} / \mathrm{Ca} \sim\right.$ $2.52 \mathrm{mmol} \mathrm{mol}^{-1}$ and $\mathrm{Sr} / \mathrm{Ca} \sim 8.72 \mathrm{mmol} \mathrm{mol}^{-1}$ ). The fraction of $\mathrm{Ca}$ remaining after a batch of calcification $(\mathrm{F}$, as shown in Figs. 5 and 6) is calculated according to Elderfield et al. (1996), and using values of 0.044 (Kitano et al., 1971) and 0.004 (Okumura and Kianto, 1986) for the $\mathrm{Sr}$ and $\mathrm{Li}$ inorganic calcite partition coefficients, respectively.

\section{Results}

$\mathrm{B} / \mathrm{Ca}, \mathrm{Li} / \mathrm{Ca}, \mathrm{Sr} / \mathrm{Ca}$ and $\mathrm{Mg} / \mathrm{Ca}$ ratios in coretop specimens of O. umbonatus are regressed against bottom water $\Delta\left[\mathrm{CO}_{3}^{2-}\right]$ (Fig. 2, Table 2). The narrow temperature range of the core top dataset limits our ability to rigorously evaluate the influence of temperature on $\mathrm{X} / \mathrm{Ca}$ ratios, although it does enable us to more robustly determine the sensitivity of $\mathrm{X} / \mathrm{Ca}$ ratios to bottom water $\Delta\left[\mathrm{CO}_{3}^{2-}\right]$. All X/Ca ratios exhibit a significant correlation with bottom water $\Delta\left[\mathrm{CO}_{3}^{2-}\right]$, although regression parameters differ depending on which hydrographic dataset is used (Table 2). This empirical approach assumes that that it is appropriate to compare core top sediment with modern hydrographic values. Depending on local sedimentation rates, the upper centimetre of the sediment column could represent several tens to thousands of year's accumulation. Some hydrographic parameters can be assumed to be relatively constant on these timescales; however over the last century the inventory of dissolved inorganic carbon (DIC) in the ocean has changed as a result of anthropogenic $\mathrm{CO}_{2}$ emissions. Several attempts have been made to estimate anthropogenic carbon uptake (see review in Sabine and Tanhua, 2010), including a study that utilized the GLODAP data set (Waugh et al., 2006). It is possible therefore to calculate pre-industrial DIC and $\Delta\left[\mathrm{CO}_{3}^{2-}\right]$ by correcting measured DIC for anthropogenic uptake, and this approach has been adopted previously (Yu and Elderfield, 2007; Lear et al., 2010). Anthropogenic carbon uptake is spatially heterogeneous (Sabine et al., 2004) and large areas of the oceans are poorly represented 

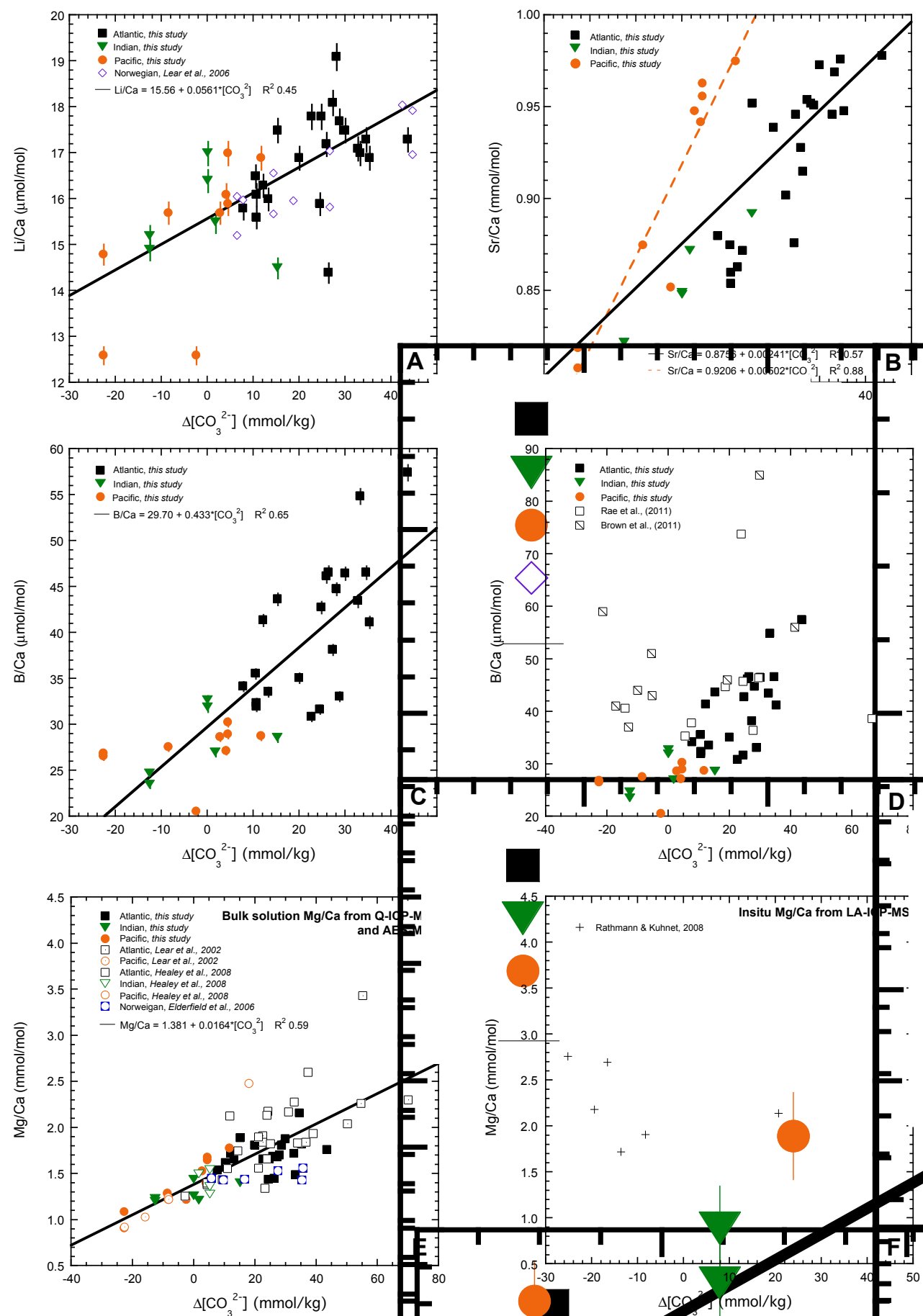

Fig. 2. Correlation of coretop O. umbonatus $\mathrm{X} / \mathrm{Ca}$ with bottom water $\Delta\left[\mathrm{CO}_{3}^{2-}\right]$. Panels (A-E) show data for different $\mathrm{X} / \mathrm{Ca}$ ratios: (A) Li/Ca, (B) $\mathrm{B} / \mathrm{Ca}$, (C) $\mathrm{Sr} / \mathrm{Ca}$, and (D) and (E) $\mathrm{Mg} / \mathrm{Ca}$ ratios. Data are displayed by basin (squares denote Atlantic Ocean samples, inverted triangles denote Indian Ocean, circles denote Pacific Ocean, locations detailed in Table 1), method, and laboratory. Refer to individual panel key for sources of published data. All data, with the exception of Rathmann and Kuhnert, were attained by bulk solution ICP-MS and Mg/Ca has been corrected for differences in the cleaning protocol (i.e. oxidative vs reductive cleaning). The data from Rathmann and Kuhnert (2008) were attained from laser-ablation ICP-MS (E). Error bars denote the analytical precision of $\mathrm{Li} / \mathrm{Ca}$ and $\mathrm{B} / \mathrm{Ca}$ ratios measured in this study is $\sim 2 \%$ (relative standard deviation, rsd). The error on $\mathrm{Sr} / \mathrm{Ca}$ and $\mathrm{Mg} / \mathrm{Ca}$ values is smaller the values represented by the size of the data symbols. Lines denote linear least square regressions. Regression equations, uncertainties and statistics are shown in Table 2. 

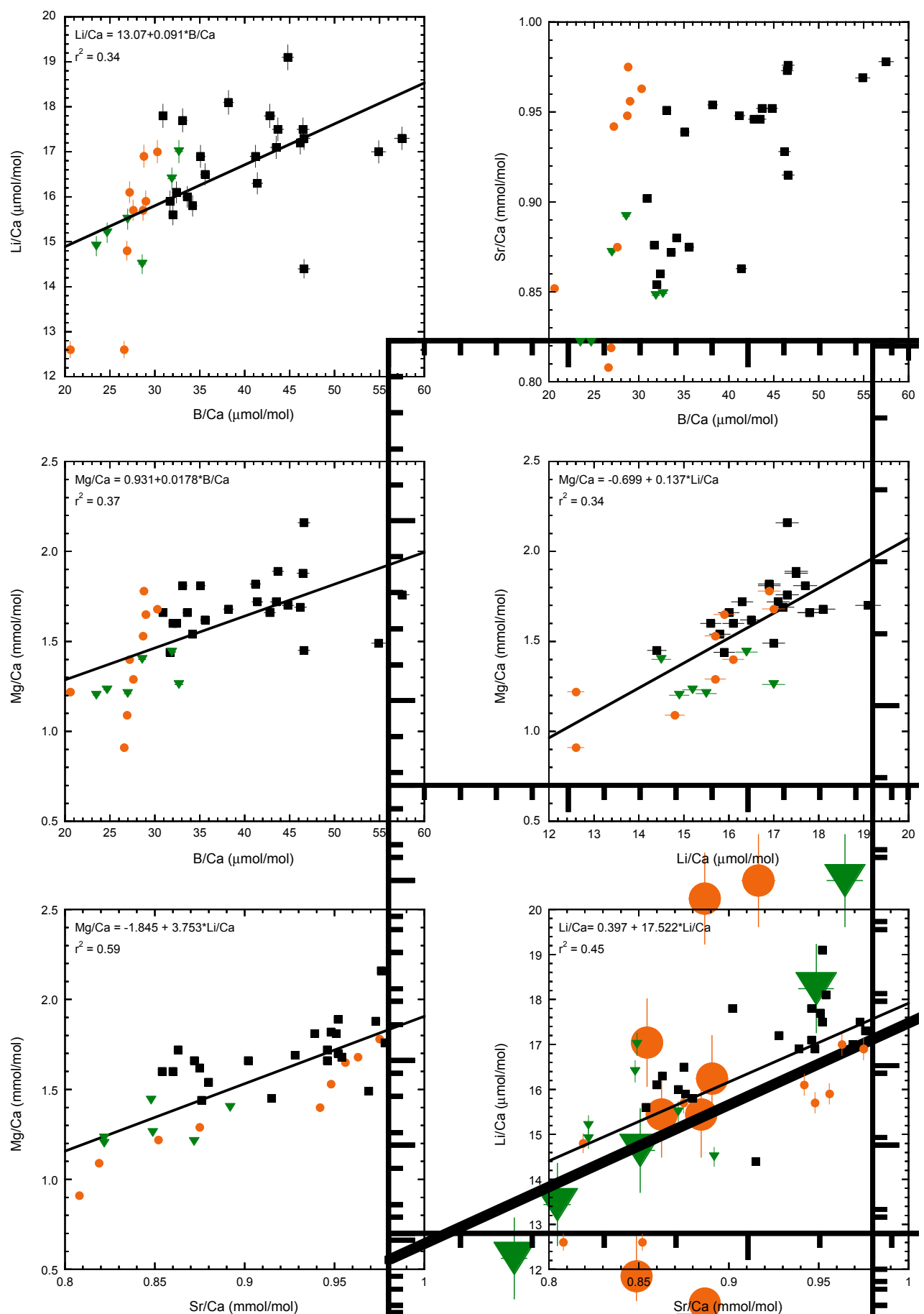

Fig. 3. Cross-plots of O. umbonatus coretop X/calcium ratios. Error bars denote analytical precision (as in Fig. 2) and dashed lines are linear least square regressions. Symbols denote ocean basin, as in Fig. 2.

in the GLODAP data set. As a result, pre-anthropogenic DIC estimates may contain significant bias if hydrographic data needs to be interpolated over significant distances. The empirical strategy adopted here has been to utilize the data sets with the greatest spatial coverage (i.e., to use both CARINA and GLODAP data sets). We also note that anthropogenic carbon uptake has not yet penetrated many of the bottom water environments examined in this study, and that the majority of core top samples in this study lack unequivocal preor post-industrial age constraints (Rose Bengal staining or ${ }^{14} \mathrm{C}$-AMS dates). We calculate regression statistics for both 

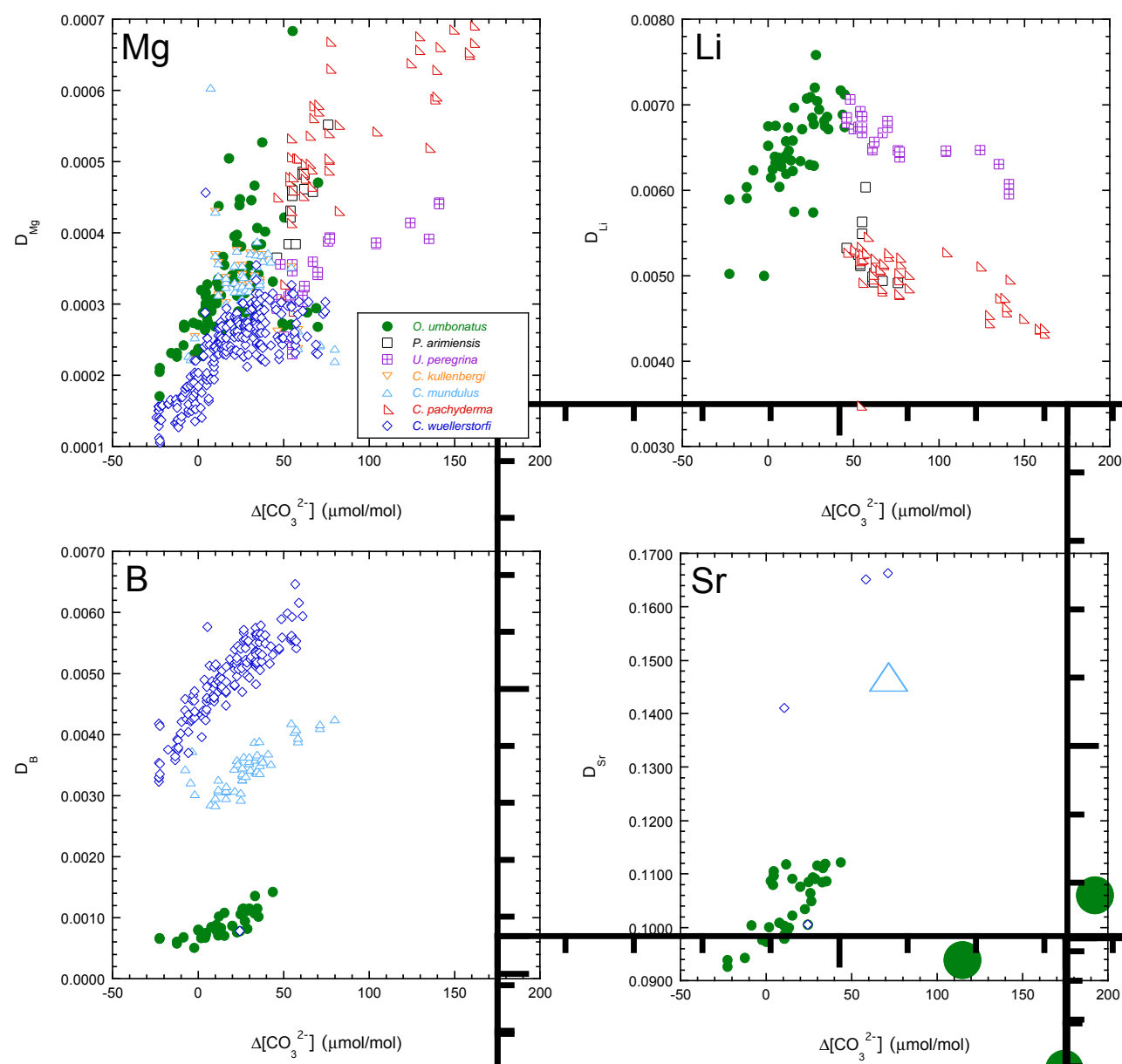

Fig. 4. Benthic foraminifera empirical partition coefficients as a function of bottom water $\Delta\left[\mathrm{CO}_{3}^{2-}\right]$. Partition coefficients calculated from new and published benthic foraminifera element ratios (Lear et al., 2002, 2003; Lear and Rosenthal, 2006; Elderfield et al., 2006; Yu and Elderfield, 2007, 2008; Bryan and Marchitto, 2008; Healey et al., 2008) and modern seawater composition $\left(\mathrm{Li} / \mathrm{Ca} \sim 0.00252 \mathrm{~mol} \mathrm{~mol}^{-1}\right.$, $\mathrm{B} / \mathrm{Ca} \sim 0.0404 \mathrm{~mol} \mathrm{~mol}^{-1}, \mathrm{Mg} / \mathrm{Ca} \sim 5.31 \mathrm{~mol} \mathrm{~mol}^{-1}$ and $\mathrm{Sr} / \mathrm{Ca} \sim 0.00872 \mathrm{~mol} \mathrm{~mol}^{-1}$ ).

modern $\Delta\left[\mathrm{CO}_{3}^{2-}\right]$ and pre-industrial $\Delta\left[\mathrm{CO}_{3}^{2-}\right]$ scenarios, but illustrate only the uncorrected $\Delta\left[\mathrm{CO}_{3}^{2-}\right]$ regressions (Fig. 2).

The relationship between $\mathrm{X} / \mathrm{Ca}$ and bottom water $\Delta\left[\mathrm{CO}_{3}^{2-}\right]$ varies, with $\mathrm{B} / \mathrm{Ca}$ ratios exhibiting the largest regression coefficient and $\mathrm{Mg} / \mathrm{Ca}$ displaying the smallest regression coefficient. There is some indication that the relationship between $\mathrm{Sr} / \mathrm{Ca}$ ratios and bottom water $\Delta\left[\mathrm{CO}_{3}^{2-}\right]$ may be different in the separate ocean basins (Fig. 2b). O. umbonatus $\mathrm{Sr} / \mathrm{Ca}$ from the Pacific Ocean appear to exhibit a larger regression coefficient. The source of this difference is unclear, but it does not appear to reflect a specific $\Delta\left[\mathrm{CO}_{3}^{2-}\right]-$ threshold as has been reported for benthic $\mathrm{Mg} / \mathrm{Ca}$ (Elderfield et al., 2006). The relationship between $\mathrm{Li} / \mathrm{Ca}$ and bottom water $\Delta\left[\mathrm{CO}_{3}^{2-}\right]$ (Fig. 2a) is consistent with that published for O. umbonatus from a coretop depth transect in the Norwegian Sea, irrespective of whether or not bottom water $\Delta\left[\mathrm{CO}_{3}^{2-}\right]$ is corrected for anthropogenic DIC (Lear and Rosenthal, 2006; Lear et al., 2010). The O. umbonatus
$\mathrm{B} / \mathrm{Ca}$ data presented here is within the range previously presented by Rae et al. (2011) and Brown et al. (2011). However, although there is a good agreement between the relationship of $O$. umbonatus and bottom water $\Delta\left[\mathrm{CO}_{3}^{2-}\right]$ presented here and in Rae et al. (2011), there are some notable discrepancies with the relationship presented by Brown et al. (2011) (Fig. 2d). These discrepancies may arise from several sources, possibly including sample size and differences in analytical acquisition. The data presented here was acquired using the method of Yu et al. (2005) that uses matrixmatched Ca concentrations at $100 \mathrm{ppm} \mathrm{Ca}$, a method that has been used in several studies (Yu and Elderfield, 2007; Yu et al., 2007; Hendry et al., 2009; Tripati et al., 2009; Rickaby et al., 2010; Allen et al., 2011; Dawber and Tripati, 2011b; Tripati et al., 2011). In contrast, the data presented in Brown et al. (2011) was measured using variable Ca concentrations. It has been observed that on some mass spectrometers, the accuracy of some element ratios, including $\mathrm{B}$, is sensitive to the 

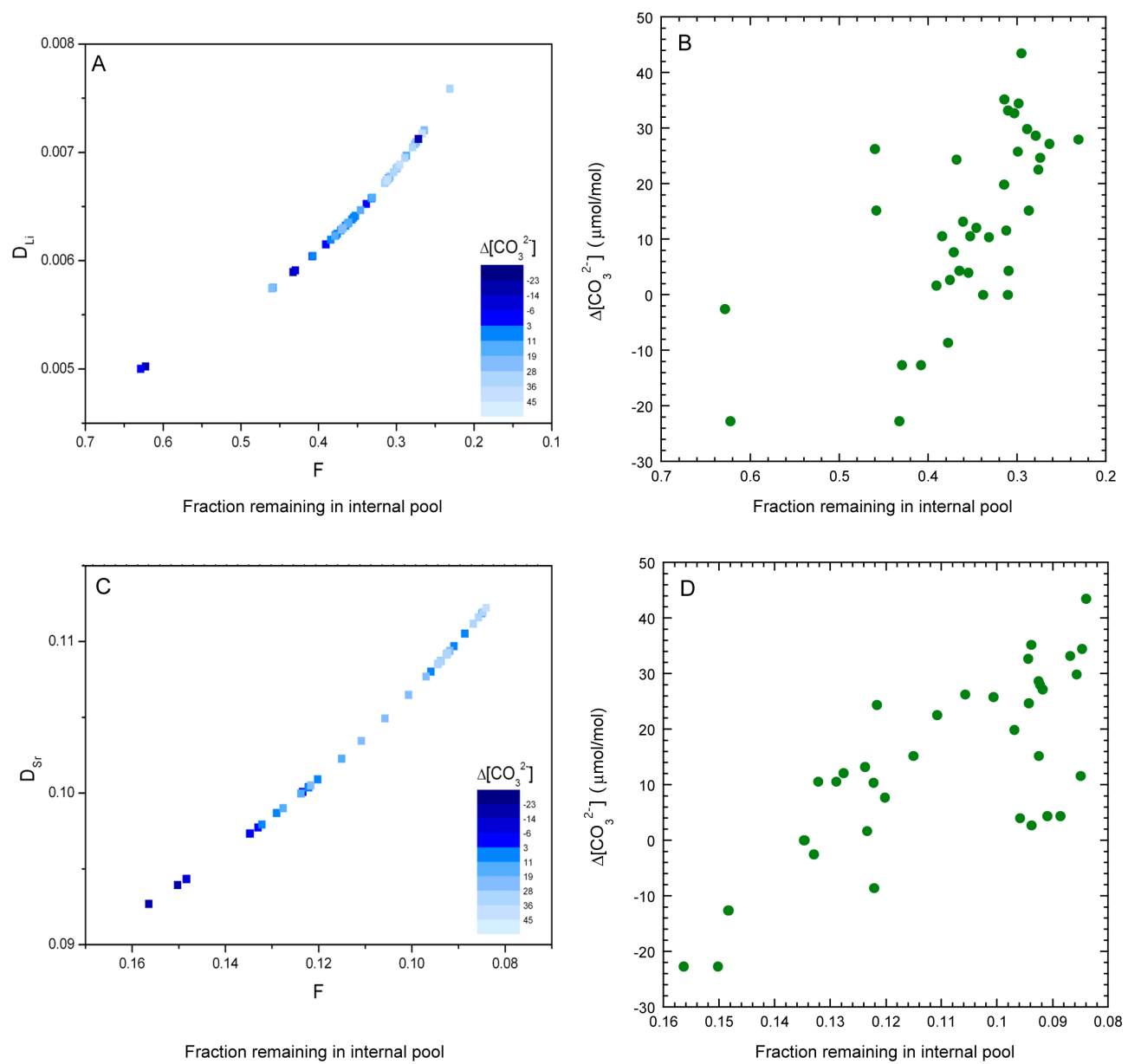

Fig. 5. Relationships between $O$. umbonatus empirical partition coefficients $\left(D_{L i}\right.$ panel $\mathbf{A} ; D_{\mathrm{Sr}}$ panel $\left.\mathbf{C}\right)$ and measured bottom water $\Delta\left[\mathrm{CO}_{3}^{2-}\right]$ (corresponding to $\mathrm{Li}$ data, panel $\mathbf{B}$ and $\mathrm{Sr}$ data, panel $\mathbf{D}$ ) with the fraction of Ca remaining in the internal pool after of calcification.

[Ca] matrix of the sample relative to the calibration standards (e.g. Yu et al., 2005; Dawber and Tripati, 2011b).

The consistency of the Brown et al. (2011) B/Ca data for $C$. wuellerstorfi with that presented in Yu and Elderfield (2007) implies the accuracy of the two methods is comparable, and therefore other sources are responsible for the discrepancies with the $O$. umbonatus $\mathrm{B} / \mathrm{Ca}$ presented here. However, we note that $C$. wuellerstorf $i$ has an absolute $\mathrm{B} / \mathrm{Ca}$ within the range of $130-260 \mu \mathrm{mol} \mathrm{mol}^{-1}$ compared to $\mathrm{B} / \mathrm{Ca}$ in $O$. umbonatus of $\sim 20-70 \mu \mathrm{mol}^{-1}$. As a result, the potential impact of variable [Ca] concentrations on the accuracy of $\mathrm{B} / \mathrm{Ca}$ measurements will be relatively greater for $O$. umbonatus compared to $C$. wuellerstorfi(i.e., the influence of variable $\mathrm{Ca}$ concentrations, or $\mathrm{Ca}$ matrix effects, on $\mathrm{B}$ and $\mathrm{B} / \mathrm{Ca}$ determination at low $\mathrm{B}$ concentrations are likely to be greater than at high B concentrations). At this time, it is not clear if the differences in data acquisition are the source of the discrepancies and further studies are needed to clarify this issue.

Linear regressions of the individual X/Ca ratios (Fig. 3) demonstrate that some component of the observed coretop variability may be explained by a common factor, possibly bottom water $\Delta\left[\mathrm{CO}_{3}^{2-}\right]$. However, it is clear that other parameters must also influence some/all of the $\mathrm{X} / \mathrm{Ca}$ ratios, and that the sensitivity of individual $\mathrm{X} / \mathrm{Ca}$ ratios to these additional parameters may not be constant. The cross plots of element ratios also highlight that the relationship in the Pacific may be different to other basins. We chose not to distinguish between morphotypes in order to get sufficient sample sizes for analysis and to examine the elemental composition of the notional species. We acknowledge that morphotypes and/or cryptic species of $O$. umbonatus, which are likely to have discrete and distinct geographical ranges, may have different element compositions. At this time, there is no evidence to support this caveat, but future genetic analysis and expansion of the core top data set, may allow this hypothesis to be tested. 

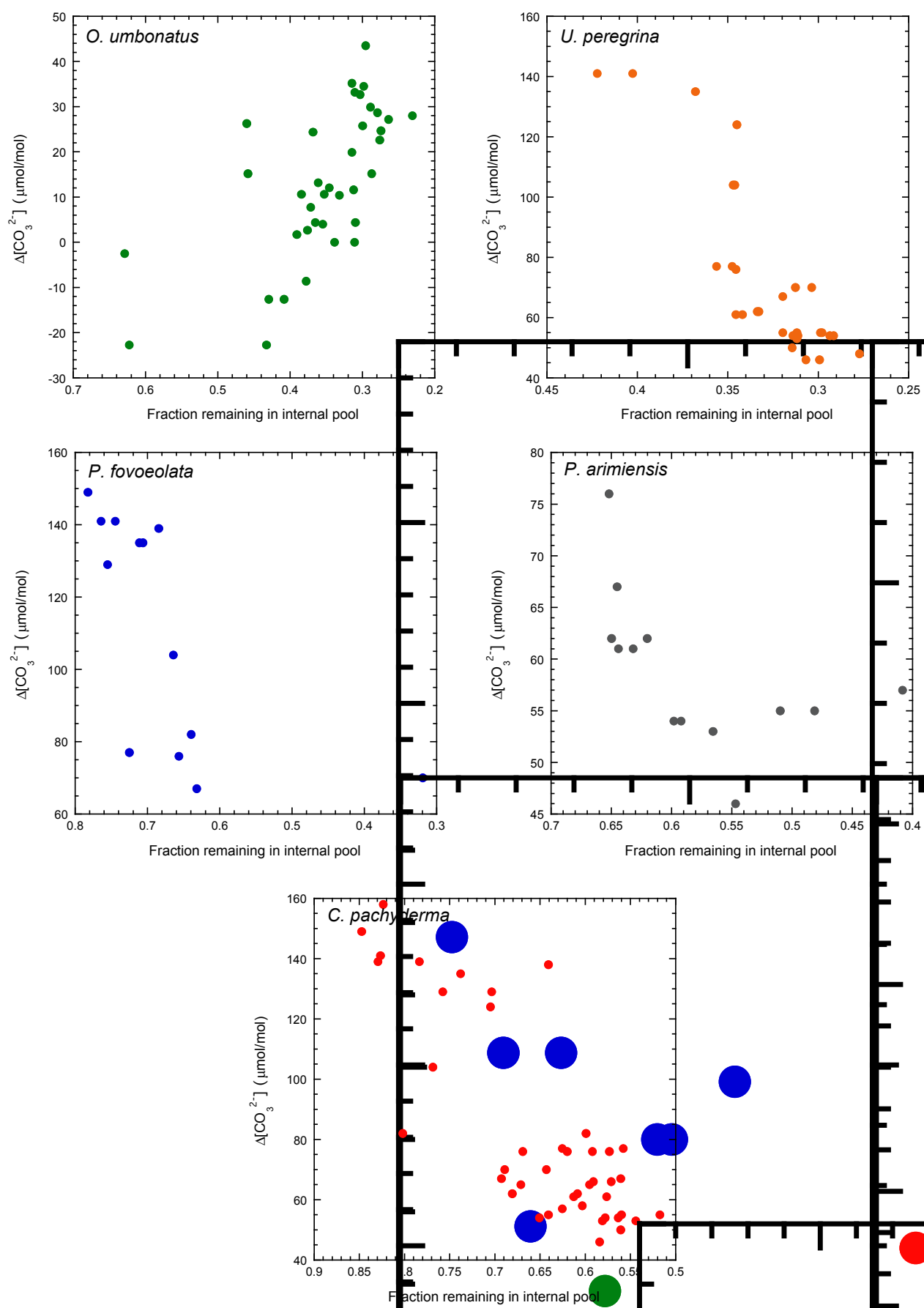

Fig. 6. The relationship between bottom water $\Delta\left[\mathrm{CO}_{3}^{2-}\right]$ and the fraction of Ca remaining in the internal pool after calcification calculated from $\mathrm{Li}$ empirical partition coefficients for O. umbonatus and other benthic species. Empirical partition coefficients and data sources as in Fig. 4.

\section{Discussion}

Elemental data for core-top specimens suggests there is a relationship between $O$. umbonatus $\mathrm{Li} / \mathrm{Ca}, \mathrm{B} / \mathrm{Ca}, \mathrm{Mg} / \mathrm{Ca}$, $\mathrm{Sr} / \mathrm{Ca}$ and bottom water $\Delta\left[\mathrm{CO}_{3}^{2-}\right]$. However, with purely empirical basis, it is not always clear if correlations between
$\mathrm{X} / \mathrm{Ca}$ and bottom water $\Delta\left[\mathrm{CO}_{3}^{2-}\right]$ reflect a genuine causal relationship or reflect the covariation of $\Delta\left[\mathrm{CO}_{3}^{2-}\right]$ with other hydrographic parameters that influence $\mathrm{X} / \mathrm{Ca}$. One strategy to assess the fidelity of these apparent relationships is to examine the mechanistic cause and evaluate if the data are 
Table 2. Linear least square regression models fitted through $\mathrm{X} / \mathrm{Ca}$ and $\Delta\left[\mathrm{CO}_{3}^{2-}\right]$ data.

\begin{tabular}{|c|c|c|c|c|c|c|c|c|c|c|c|c|}
\hline \multirow[b]{2}{*}{$\mathrm{X} / \mathrm{Ca}$} & \multirow[b]{2}{*}{ Dataset used } & \multirow[b]{2}{*}{$\begin{array}{l}T \text { range } \\
\left({ }^{\circ} \mathrm{C}\right)\end{array}$} & \multirow[b]{2}{*}{$\begin{array}{l}\Delta\left[\mathrm{CO}_{3}^{2-}\right] \text { range } \\
\left(\mu \mathrm{mol} \mathrm{kg}^{-1}\right)\end{array}$} & \multirow[b]{2}{*}{$n$} & \multicolumn{4}{|c|}{$\Delta\left[\mathrm{CO}_{3}^{2-}\right]$ not corrected for Anthropogenic DIC } & \multicolumn{4}{|c|}{$\Delta\left[\mathrm{CO}_{3}^{2-}\right]$ corrected for Anthropogenic DIC } \\
\hline & & & & & $\begin{array}{l}\text { Slope } \\
\left(\mathrm{mmol} \mathrm{mol}^{-1 /}\right. \\
\mu \mathrm{mol} \mathrm{kg} \\
\text { except for B/Ca } \\
\text { and } \mathrm{Li} / \mathrm{Ca}- \\
\mu \mathrm{mol} \mathrm{mol} \\
\mu \mathrm{mol} \mathrm{kg}-1\end{array}$ & Intercept & $R^{2}$ & $\mathrm{p}$-value & $\begin{array}{l}\text { Slope } \\
\left(\mathrm{mmol} \mathrm{mol}^{-1 /}\right. \\
\mu \mathrm{mol} \mathrm{kg} \\
\text { except for B/Ca } \\
\text { and } \mathrm{Li} / \mathrm{Ca}- \\
\mu \mathrm{mol} \mathrm{mol}-1 \\
\left.\mu \mathrm{mol} \mathrm{kg}{ }^{-1}\right)\end{array}$ & Intercept & $R^{2}$ & $\mathrm{p}$-value \\
\hline $\mathrm{B} / \mathrm{Ca}$ & This study & 1.1 to 3.6 & -23 to 44 & 37 & $0.433 \pm 0.053$ & $29.7 \pm 1.1$ & 0.65 & $1.5 \mathrm{e}-9$ & $0.369 \pm 0.045$ & $29.9 \pm 1.1$ & 0.66 & $1.3 \mathrm{e}-9$ \\
\hline \multirow[t]{3}{*}{$\mathrm{Li} / \mathrm{Ca}$} & All datasets & -0.8 to 3.6 & -23 to 45 & 44 & $0.0526 \pm 0.0084$ & $15.53 \pm 0.19$ & 0.46 & $1.1 \mathrm{e}-7$ & & & & \\
\hline & This study & 1.1 to 3.6 & -23 to 44 & 37 & $0.0561 \pm 0.0105$ & $15.56 \pm 0.22$ & 0.45 & $6.2 \mathrm{e}-6$ & $0.0466 \pm 0.0091$ & $15.60 \pm 0.22$ & 0.43 & $1.2 \mathrm{e}-5$ \\
\hline & Lear et al. (2006) & -0.8 to 0.6 & 6 to 45 & 9 & 0.0515 & 15.3 & 0.69 & 0.00149 & & & & \\
\hline $\mathrm{Sr} / \mathrm{Ca}$ & This study & 1.1 to 3.6 & -23 to 44 & 37 & $0.00241 \pm 0.0004$ & $0.8756 \pm 0.0074$ & 0.57 & $7.4 \mathrm{e}-8$ & $0.00207 \pm 0.0003$ & $0.8764 \pm 0.0072$ & 0.58 & $5.2 \mathrm{e}-8$ \\
\hline \multirow[t]{7}{*}{$\mathrm{Mg} / \mathrm{Ca}$} & $\begin{array}{l}\text { All datasets (except } \\
\text { Rathmann and Kuhnert, } \\
\text { 2007) }\end{array}$ & -0.9 to 10.5 & 25 to 70 & 83 & $0.0164 \pm 0.0016$ & $1.381 \pm 0.0366$ & 0.59 & $1.7 \mathrm{e}-9$ & $0.0102 \pm 0.0014$ & $1.413 \pm 0.05$ & 0.41 & $9.6 \mathrm{e}-11$ \\
\hline & $\begin{array}{l}\text { Same but multiple } \\
\text { linear regression } \\
\text { (Table 3) }\end{array}$ & -0.9 to 10.5 & 25 to 70 & 83 & $0.017 \pm 0.002$ & $1.199 \pm 0.055$ & $1.472 \pm 0.043$ & $1.5 \mathrm{e}-14$ & $0.0083 \pm 0.001$ & $1.215 \pm 0.054$ & 0.56 & $3.2 \mathrm{e}-9$ \\
\hline & This study & 1.1 to 3.6 & -23 to 44 & 37 & $0.0122 \pm 0.0016$ & $1.400 \pm 0.034$ & 0.61 & $1.8 \mathrm{e}-8$ & $0.00992 \pm 0.0015$ & $1.412 \pm 0.036$ & 0.56 & $1.6 \mathrm{e}-7$ \\
\hline & Healey et al. (2008) & 1.2 to 4 & -3 to 39 & 24 & $0.0227 \pm 0.0049$ & $1.355 \pm 0.105$ & 0.49 & $1.3 e-4$ & & & & \\
\hline & Elderfield et al. (2006) & -0.9 to -0.8 & 6 to 36 & 6 & & & & & $0.0024 \pm 0.0019$ & $1.422 \pm 0.048$ & 0.27 & 0.298 \\
\hline & Lear et al. (2002) & 0.8 to 10.5 & -22 to 0 & 16 & $0.0190 \pm 0.0032$ & $1.382 \pm 0.087$ & 0.76 & $1.3 e-5$ & & & & \\
\hline & $\begin{array}{l}\text { Rathmann and } \\
\text { Kuhnert (2008) }\end{array}$ & 1.6 to 10.4 & -25 to 21 & 6 & $-0.0092 \pm 0.0119$ & $2.137 \pm 0.217$ & 0.13 & & & & & \\
\hline
\end{tabular}

consistent with existing models explaining elemental partitioning into calcium carbonate, which we examine below. A second strategy, presented elsewhere (Dawber and Tripati, 2011b), is to apply these relationships to down core records of $O$. umbonatus $\mathrm{X} / \mathrm{Ca}$ and assess the consistency of the $\Delta\left[\mathrm{CO}_{3}^{2-}\right]$ reconstructions based on multi-element data and comparisons with other proxy data. Here, we examine the compatibility of the $O$. umbonatus $\mathrm{X} / \mathrm{Ca}$ with hypothesized models of inorganic and foraminiferal mineralisation.

\subsection{Surface entrapment model}

Experimentally determined Sr inorganic calcite partition coefficients are controlled by precipitation rate and are temperature sensitive (Tang et al., 2008). Sr incorporation in inorganic calcite is consistent with the surface entrapment model (SEMO, Watson and Liang, 1995; Watson, 2004; Tang et al., 2008) and to a first approximation, Sr inorganic partition coefficients can be used as an indicator of precipitation rate if changes in $\mathrm{pH}$ and temperature are not significant (Tang et al., 2008). Empirical partition coefficients $\left(D_{X}\right)$ for $O$. umbonatus and other species of benthic foraminifera as a function of bottom water $\Delta\left[\mathrm{CO}_{3}^{2-}\right]$ are shown in Fig. 4. B; $\mathrm{Mg}$ and $\mathrm{Sr}$ empirical partition coefficients increase with increasing bottom water $\Delta\left[\mathrm{CO}_{3}^{2-}\right]$. Li empirical partition coefficients for $O$. umbonatus increase with increasing bottom water $\Delta\left[\mathrm{CO}_{3}^{2-}\right]$ but decrease with increasing bottom water $\Delta\left[\mathrm{CO}_{3}^{2-}\right]$ for other benthic species. Assuming that the positive relationship between seawater $\left[\mathrm{CO}_{3}^{2-}\right]$ (and $\left.\Delta\left[\mathrm{CO}_{3}^{2-}\right]\right)$ and calcification rate established for planktonic foraminifera (Russell et al., 2004) is also applicable to benthic foraminifera, O. umbonatus $\mathrm{Li}, \mathrm{B}, \mathrm{Mg}$ and $\mathrm{Sr}$ partition coefficients positively correlate with calcification rate, suggesting that $\mathrm{Li}, \mathrm{B}, \mathrm{Mg}$ and $\mathrm{Sr}$ incorporation could be consistent with the SEMO. In the SEMO, the increase in Sr inorganic partition coefficients with increasing precipitation rate reflects the progressive retainment of $\mathrm{Sr}$ from the enriched surface layer as the precipitation rate exceeds $\mathrm{Sr}$ lattice diffusion rates. It is interesting that $\mathrm{Li}, \mathrm{B}, \mathrm{Mg}$ and $\mathrm{Sr}$ exhibit similar relationships with $\Delta\left[\mathrm{CO}_{3}^{2-}\right]$ (and calcification rate) given their differences in ionic radius, charge and potential site location in the calcite lattice (i.e. interstitial or Ca site) and presumably, their diffusion coefficients. It should be possible to further check whether $O$. umbonatus empirical partition coefficients are consistent with the SEMO by checking the relative sensitivity of $D_{X}$ with the relative diffusion coefficients in calcite. Unfortunately, to our knowledge, there are no estimates of low temperature cation diffusion coefficients in calcite. From high temperature experiments, it is clear that diffusion coefficients in calcite cannot simply be estimated from size and charge considerations, and knowledge of the diffusion pathway (i.e. interstitial or vacancies) is important (Cherniak, 2010). Inorganic calcite precipitation experiments over the temperature and pressure range of $O$. umbonatus habitats are needed to constrain cation diffusion coefficients in order to better define any similarities between $O$. umbonatus biomineralisation and the SEMO. Interestingly, other species of benthic foraminifera exhibit a negative correlation between $\mathrm{Li}$ empirical partition coefficients and bottom water $\Delta\left[\mathrm{CO}_{3}^{2-}\right]$ (and presumably calcification rate, Fig. 4), which suggests that $\mathrm{Li}$ incorporation and perhaps other ions in foraminiferal calcite does not follow the SEMO. The inorganic precipitation experiments of Marriott et al. (2004), which demonstrate a negative relationship 
between temperature and Li partition coefficients also support the hypothesis that Li may be controlled by different processes than other element ratios.

\subsection{Rayleigh fractionation}

Seawater vacuoles are thought to be the main source of ions in foraminiferal calcite (Erez, 2003). In a conceptual model, Elderfield et al. (1996) described the evolution of empirical partition coefficients as a function of the amount of Ca remaining in an internal pool serving calcification. In the semienclosed pool, cations are incorporated into foraminiferal calcite with a constant fractionation factor, assumed to be the inorganic partition coefficient. Empirical $\mathrm{Sr}$ and $\mathrm{Li}$ partition coefficients for $O$. umbonatus $(0.09-0.11$ and $0.005-$ 0.0075 , respectively) are larger than the inorganic calcite partition coefficients (0.04 and 0.004, Lorens, 1978, 1981; Elderfield et al., 1996; Okumura and Kitano, 1986), but less than one, consistent with calcification from a semi-enclosed pool that is modified via Rayleigh fractionation. In contrast, $\mathrm{Mg}$ and B empirical partition coefficients for O. umbonatus (0.00017-0.00068 and 0.0005-0.0014 respectively) are significantly lower than the inorganic partition coefficients (0.0573 and 0.38-4.0 respectively, Katz, 1973; Gabitov et al., 2011; Hemming et al., 1995). This observation does not preclude a Rayleigh fractionation mechanism in O. umbonatus, but indicates that for $\mathrm{Mg}$ and $\mathrm{B}$, either the fractionation factor from the internal pool is significantly smaller than the inorganic partition coefficient, or there are additional mechanisms contributing to the partition coefficients.

If Rayleigh fractionation is controlling partition coefficients in $O$. umbonatus, $\mathrm{Sr}$ partition coefficients imply that $\sim 84-92 \%$ of the $\mathrm{Ca}$ in the internal pool is consumed in a single batch of calcification (Fig. 5). Similar calculations for three other benthic species (Elderfield et al., 1996) indicate that they use a slightly larger proportion of the internal pool (94-99\%) compared to O. umbonatus. O. umbonatus $\mathrm{Li}$ partition coefficients have a much wider range, indicating that $37-77 \%$ of the $\mathrm{Ca}$ is used during each batch of calcification (Fig. 6). This range in the proportion of $\mathrm{Ca}$ used from the internal pool overlaps the range observed in other benthic species (Fig. 6). But interestingly, the infaunal species $(O$. umbonatus and $U$. peregrina $)$ appear to use a greater proportion of the $\mathrm{Ca}$ in the internal pool than the epifaunal species (Fig. 6). Infaunal species likely calcify from pore waters and so will be influenced by pore water $\Delta\left[\mathrm{CO}_{3}^{2-}\right]$ rather than bottom water $\Delta\left[\mathrm{CO}_{3}^{2-}\right]$. As a first order observation, pore water $\Delta\left[\mathrm{CO}_{3}^{2-}\right]$ tends away from bottom water $\Delta\left[\mathrm{CO}_{3}^{2-}\right]$ in the sediment column towards zero (Martin and Sayles, 1996). Our observation that two infaunal species appear to use a greater proportion of $\mathrm{Ca}$ in the internal pool may reflect an evolutionary adaptation of these species to living in environments of variable and possibly low pore water $\Delta\left[\mathrm{CO}_{3}^{2-}\right]$. Additional elemental data for other

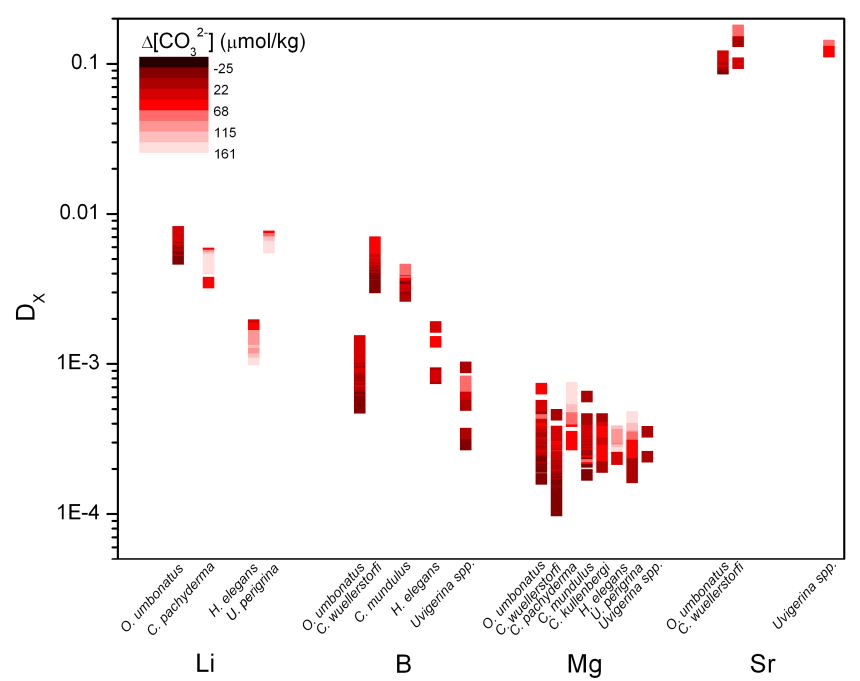

Fig. 7. Benthic foraminifera empirical partition coefficients as a function of bottom water $\Delta\left[\mathrm{CO}_{3}^{2-}\right]$. Partition coefficients calculated from new and published benthic foraminifera element ratios (Lear et al., 2002, 2003; Lear and Rosenthal, 2006; Elderfield et al., 2006; Yu and Elderfield, 2007, 2008; Bryan and Marchitto, 2008; Healey et al., 2008) and modern seawater composition $\left(\mathrm{Li} / \mathrm{Ca} \sim 0.00252 \mathrm{~mol} \mathrm{~mol}^{-1}, \mathrm{~B} / \mathrm{Ca} \sim 0.0404 \mathrm{~mol} \mathrm{~mol}^{-1}\right.$, $\mathrm{Mg} / \mathrm{Ca} \sim 5.31 \mathrm{~mol} \mathrm{~mol}^{-1}$ and $\mathrm{Sr} / \mathrm{Ca} \sim 0.00872 \mathrm{~mol} \mathrm{~mol}^{-1}$ ).

infaunal species is needed to explore this hypothesis. However, O.umbonatus and U. peregrina appear to exhibit opposite relationships between the fraction of $\mathrm{Ca}$ in the internal pool and bottom water $\Delta\left[\mathrm{CO}_{3}^{2-}\right]$ (Fig. 6), further demonstrating the specificity of biomineralisation in different species. Empirical partition coefficients for different species of benthic foraminifera as a function of saturation state are shown in Figs. 7 and 8.

For $\mathrm{Sr}$ and $\mathrm{Li}$ partition coefficients in $O$. umbonatus there is a well defined, positive correlation between the fraction of the internal $\mathrm{Ca}$ pool is used for calcification and ambient seawater $\Delta\left[\mathrm{CO}_{3}^{2-}\right]$ (Figs. 5 and 6). In contrast, the opposite relationship is observed for the four other benthic species for which $\mathrm{Li} / \mathrm{Ca}$ data are available (Fig. 6). One way to account for the positive correlation between the apparent fraction of the $\mathrm{Ca}$ pool consumed during calcification and ambient seawater $\Delta\left[\mathrm{CO}_{3}^{2-}\right]$ in $O$. umbonatus is the through the influence of seawater $\Delta\left[\mathrm{CO}_{3}^{2-}\right]$ on calcification rate, i.e. high seawater $\Delta\left[\mathrm{CO}_{3}^{2-}\right]$ results in high calcification rates that consume a greater proportion of $\mathrm{Ca}$ in the internal pool before replenishing/flushing. This scenario assumes a somewhat constant replenishing/flushing rate of the internal $\mathrm{Ca}$ pool. It is not known whether the replenishing/flushing rate would also be dependent on calcification rate, for example, if flushing rate positively correlates with calcification rate, the higher frequency of flushing expected at higher seawater $\Delta\left[\mathrm{CO}_{3}^{2-}\right]$ would correlate with proportionally lesser amounts of $\mathrm{Ca}$ consumption per batch. This prediction is opposite to that 

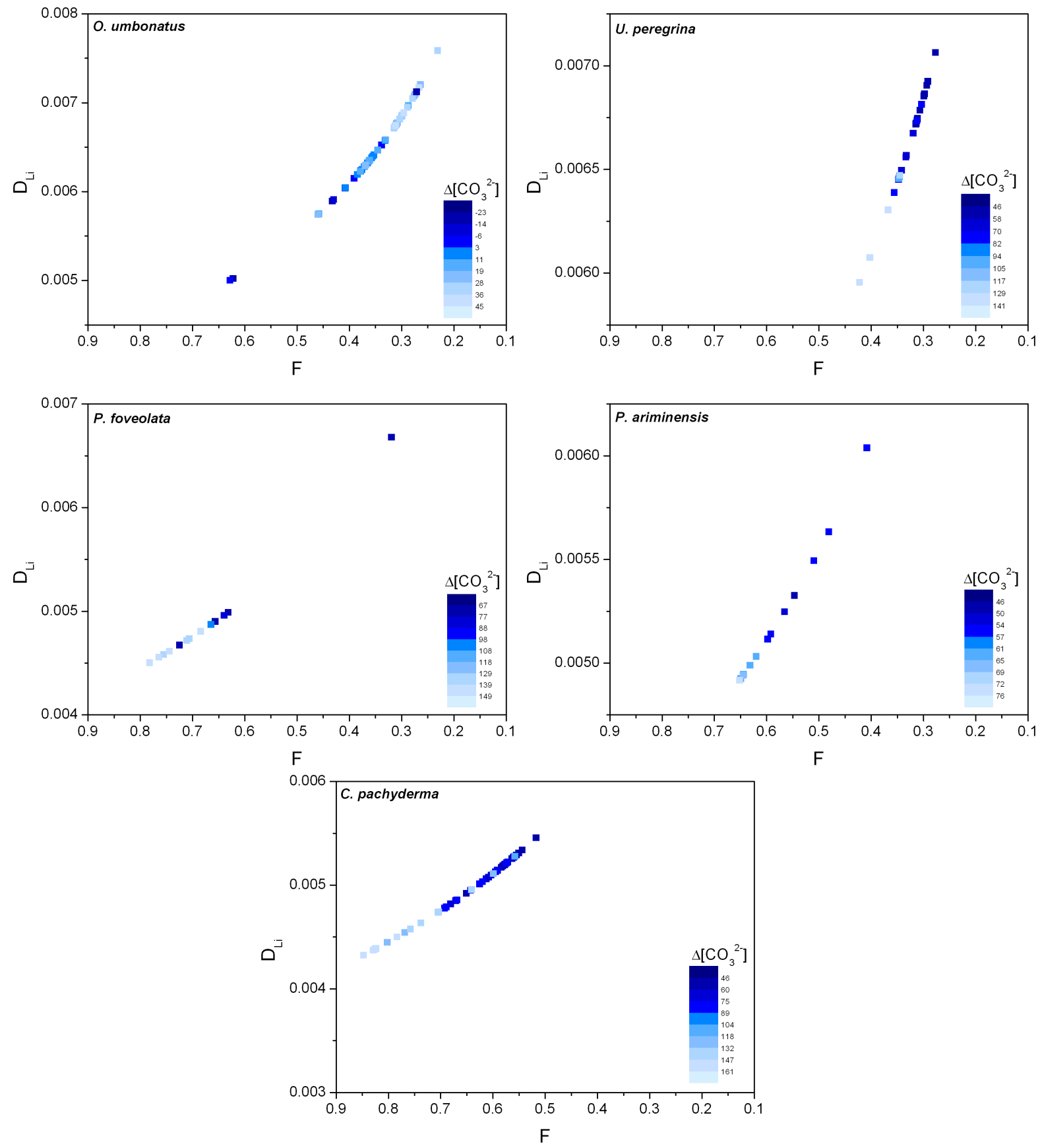

Fig. 8. The relationship between Li empirical partition coefficients, the fraction of Ca remaining in the internal pool after calcification and bottom water $\Delta\left[\mathrm{CO}_{3}^{2-}\right]$ for $O$. umbonatus and other benthic species. Empirical partition coefficients and data sources as in Fig. 3.

observed in $O$. umbonatus, but is consistent with the Li partition coefficients for four other benthic species.

Recently, it has been observed that benthic foraminifera raise the $\mathrm{pH}$ of vesicles at the site of calcification, which is thought to be a widespread strategy for increasing $\left[\mathrm{CO}_{3}^{2-}\right]$ to promote calcification (Erez, 2003; de Nooijer et al., 2009). Although the energy consumption associated with raising vesicle $\mathrm{pH}$ (and $\left[\mathrm{CO}_{3}^{2-}\right]$ ) is unconstrained, and is likely a complex process that will depend on the presence of other ions (e.g. Mg, Zeebe and Sanyal, 2002), it is a reasonable first order assumption that it will be inversely related to initial vacuole (and therefore seawater) $\Delta\left[\mathrm{CO}_{3}^{2-}\right]$. If Rayleigh fractionation occurs in tandem with increased vesicle $\mathrm{pH}$, it follows that foraminifera that vacuolise low $\Delta\left[\mathrm{CO}_{3}^{2-}\right]$ seawater 
require more energy to raise vesicle $\mathrm{pH}$. Hence it would be energetically more efficient to replenish/flush the internal pool less frequently; therefore, presumably a greater proportion of the pool would be consumed during each batch of calcification. This hypothesis predicts a negative correlation between the fraction of $\mathrm{Ca}$ consumed from the internal pool and bottom water $\Delta\left[\mathrm{CO}_{3}^{2-}\right]$, which is observed in $U$. peregrina, $C$. pachyderma, $P$. foveolata and $P$. ariminensis but is opposite to the trend observed in O. umbonatus (Fig. 6).

If $\mathrm{Sr}$ and $\mathrm{Li}$ discrimination in benthic foraminifera is controlled by Rayleigh fractionation from an internal pool, our observations suggest that there may be significant differences in the replenishing/flushing dynamics of the internal pool between species. To reconcile the positive correlation between the fraction of the internal pool consumed per batch of fluid used for calcification that is vacuolized and bottom water $\Delta\left[\mathrm{CO}_{3}^{2-}\right]$ in $O$. umbonatus, the replenishing/flushing frequency of the internal pool must be relatively insensitive to $\Delta\left[\mathrm{CO}_{3}^{2-}\right]$. Assuming an approximately constant replenishing/flushing rate, $O$. umbonatus individuals that vacuolise low $\Delta\left[\mathrm{CO}_{3}^{2-}\right]$ seawater will require greater energy to raise vesicle $\mathrm{pH}$ to overcome calcification barriers, and would calcify more slowly and therefore use less of their internal pool.

\subsection{Multiple calcite phases in foraminifera test}

The inter-test heterogeneity of some elements in foraminiferal tests (Szafranek and Erez, 1993; Eggins et al., 2004; Anand and Elderfield, 2005; Sadekov et al., 2005; Kunioka et al., 2006) may reflect the presence of distinct types of calcite. Alternating bands of "high-Mg" (7.0$\left.10.0 \mathrm{mmol} \mathrm{mol}^{-1}\right)$ and "low-Mg" ( $\left.\sim 3.0-5.5 \mathrm{mmol} \mathrm{mol}^{-1}\right)$ calcite are observed in O. universa and Globigerinoides sp. High $\mathrm{Mg}$ calcite is more soluble than low-Mg calcite (Morse and Mackenzie, 1990); therefore, the alternating bands of high- and low-Mg may reflect diurnal variations in the $\mathrm{pH}$ (up to $0.9 \mathrm{pH}$ units, Eggins et al., 2004), and $\Delta\left[\mathrm{CO}_{3}^{2-}\right]$ of the foraminiferal microenvironment as a result of the day-night, photosynthesis-respiration cycle of the algal symbionts (Eggins et al., 2004; Sadekov et al., 2005). This mechanism cannot account for the $\mathrm{Mg} / \mathrm{Ca}$ variability reported in some non-symbiotic species and benthic species (Erez, 2003; Bentov and Erez, 2005), however, a similar control on the micro-environment $\mathrm{pH}$ by the foraminifera could feasibly result in alternating high- and low-Mg calcite layers, possibly through changes in respiration or metabolism (Eggins et al., 2004; Sadekov et al., 2005). If empirical partition coefficients in $O$. umbonatus primarily reflect changes in the proportion of high- and low-Mg calcite phases, the trend of increasing $D_{X}$ with bottom water $\Delta\left[\mathrm{CO}_{3}^{2-}\right]$ would predict that the $\mathrm{Li}, \mathrm{B}$ and $\mathrm{Sr}$ concentrations would be higher in the high-Mg calcite phase. This hypothesis is testable and future microanalysis studies should aim to characterize the minor and trace element composition of the alternating bands in foraminiferal tests. We note that our inferences about the
$\mathrm{Li}$ and $\mathrm{Sr}$ composition of the high-Mg calcite phase are consistent with inorganic calcite precipitation experiments, in which $\mathrm{Li}$ and $\mathrm{Sr}$ inorganic calcite partition coefficients increase with increasing $\mathrm{Mg}$ concentration in the parent solution and solid (Mucci and Morse, 1983; Okumura and Kitano, 1986). However, previous studies of the $\mathrm{Sr} / \mathrm{Ca}$ inter-test variability in planktonic foraminifera revealed very little variation (e.g. Anand and Elderfield, 2005). If these observations extend to benthic foraminifera, it is unlikely that the Mg-layering mechanism is responsible for $\mathrm{Sr} / \mathrm{Ca}$ variations.

\subsection{The influence of other environmental parameters}

From our present understanding of foraminiferal biomineralisation, it is clear no single biomineralisation mechanism is solely controlling all four element ratios in O. umbonatus. It is also possible this observation likely reflects both our limited understanding of how and where some of these elements are incorporated into foraminiferal calcite, as well as the possible influence of other environmental parameters. Other core top data sets demonstrate a strong correlation between $\mathrm{Mg} / \mathrm{Ca}$ ratios in $O$. umbonatus and bottom water temperature (Lear et al., 2002; Rathmann et al., 2004; Healey et al., 2008) and these relationships have been employed in a number of early Cenozoic paleotemperature reconstructions. We report the reported sensitivity of $\mathrm{O}$. umbonatus $\mathrm{Mg} / \mathrm{Ca}$ to temperature (Lear et al., 2002) is much greater than the sensitivity to saturation state that we observe in our dataset. Our core top data set was specifically designed to span a very narrow temperature range $\left(1.1\right.$ to $\left.3.6^{\circ} \mathrm{C}\right)$ and a large range of saturation states, however, so it is not suitable to quantitatively determine the role of temperature. However, we note that some of the processes within the discussed biomineralisation mechanisms could be influenced by temperature, e.g. variable diffusion rates for the SEMO, variable metabolic rates for Rayleigh fractionation and the alternating high- $\mathrm{Mg} / \mathrm{low}-\mathrm{Mg}$ layers hypothesis. A similar discussion of core top data that spans large temperature range and a narrow bottom water $\Delta\left[\mathrm{CO}_{3}^{2-}\right]$ range is needed to assess the role of temperature in these biomineralisation mechanisms. An alternative approach to evaluating the role of secondary environmental parameters is to expand the empirical core top data and develop multiple regression relationships. However, the intrinsic co-variation of hydrographic parameters, specifically $\Delta\left[\mathrm{CO}_{3}^{2-}\right]$, temperature and preservation will be difficult to untangle and it may not be possible to distinguish the relative influence of individual parameters or a mechanistic cause. Statistically, the co-variation of hydrographic parameters will lead to correlations within the data set, lending additional uncertainty in the multiple regression analysis.

A third approach is to take the empirical core top regressions at face value and test the hypothesis that these relationships can be used to reconstruct down core variations in bottom water $\Delta\left[\mathrm{CO}_{3}^{2-}\right]$ that are consistent between the different 
element ratios and also compatible with existing proxy constraints. One of the main advantages of this approach is that down core multi-element reconstructions are more likely to reflect the influence of long-term changes in seawater chemistry and post depositional processes that cannot be properly explored in modern hydrographic empirical data sets. We explore this approach in a companion paper (Dawber and Tripati, 2011b), but note that the core top regressions presented here did not produce consistent reconstructions of bottom water $\Delta\left[\mathrm{CO}_{3}^{2-}\right]$ for a site in the Pacific Ocean during the middle Eocene. This contribution highlights that there is still much to be learned about the parameters influencing element incorporation in O. umbonatus, but in framing the discussion of the empirical core top dataset around biomineralisation mechanisms, we have highlighted possible avenues for future exploration. A potential uncertainty of investigating $O$. umbonatus $\mathrm{Me} / \mathrm{Ca}$ ratios as proxies for bottom water saturation state is its reported infaunal habitat, in the upper $0-4 \mathrm{~cm}$ in the sediment (Corliss, 1985; Rathburn and Corliss, 1994). Models predict that pore water $\Delta\left[\mathrm{CO}_{3}^{2-}\right]$ values may be substantially different (up to $25 \%$ ) from bottom waters and vary considerably within the upper few centimetres of the sediment (Martin and Sayles, 1996) as a result of pore water processes (e.g. respiratory oxidation of organic matter in sediments) and acid neutralisation reactions (Emerson and Bender, 1981; Archer 1991). In saturated bottom waters where pore water $\Delta\left[\mathrm{CO}_{3}^{2-}\right]$ is predicted to decrease rapidly relative to bottom waters, or in environments with high rates of respiratory driven dissolution, the reported sensitivity of benthic foraminiferal $\mathrm{Me} / \mathrm{Ca}$ ratios to bottom water $\Delta\left[\mathrm{CO}_{3}^{2-}\right]$ may be underestimated for infaunal taxa. However, it would be difficult to quantifying this uncertainty. In addition, infaunal foraminifera may migrate within the sediment in response to food availability, temperature, and carbonate saturation, which may introduce additional inaccuracies into the coretop calibration. Pore water borate concentrations may also become de-coupled from bottom water levels, as the speciation of dissolved boron is $\mathrm{pH}$-dependent (e.g. Hemming and Hanson, 1992). Borate is the species thought to be incorporated into calcium carbonate (Hemming et al., 1995; Tripati et al., 2011), therefore a shift in the speciation of the pore water boron reservoir as a result of respiratory driven dissolution and acid neutralisation reactions may introduce some bias into $\mathrm{B} / \mathrm{Ca}$-based reconstructions of $\Delta\left[\mathrm{CO}_{3}^{2-}\right]$

from infaunal taxa. The lower $\mathrm{B} / \mathrm{Ca}$ sensitivity to bottom water $\Delta\left[\mathrm{CO}_{3}^{2-}\right]$ reported for the infaunal genus Uvigerina compared to the epifaunal genus Cibicidoides (Yu and Elderfield, 2007) is consistent with this hypothesis.

\section{Summary}

The $\mathrm{B} / \mathrm{Ca}, \mathrm{Li} / \mathrm{Ca}, \mathrm{Sr} / \mathrm{Ca}$ and $\mathrm{Mg} / \mathrm{Ca}$ ratios and empirical partition coefficients for coretop specimens of the benthic foraminifera $O$. umbonatus exhibit significant, positive correlations with bottom water $\Delta\left[\mathrm{CO}_{3}^{2-}\right] . \mathrm{Mg}$ and B empirical partition coefficients are significantly smaller than inorganic partition coefficients suggesting that their incorporation into foraminiferal calcite is not primarily controlled by the surface entrapment model (Watson and Liang, 1995; Watson, 2004; Tang et al., 2008). Furthermore, the observation that $\mathrm{Li}, \mathrm{B}, \mathrm{Mg}$ and $\mathrm{Sr}$ empirical partition coefficients all exhibit a positive relationships with bottom water $\Delta\left[\mathrm{CO}_{3}^{2-}\right]$, despite their presumed differences in lattice diffusivity, may also argue against these elements being incorporated according to the SEMO. However, calcite lattice diffusion coefficients are not well constrained. Inorganic precipitation experiments at low temperatures are needed to better define relative cation diffusivities, which should help elucidate any similarities between $\mathrm{Li}, \mathrm{B}, \mathrm{Mg}$ and $\mathrm{Sr}$ incorporation in $O$. umbonatus and the SEMO.

The $\mathrm{Sr}$ and $\mathrm{Li}$ data for $O$. umbonatus is consistent with the Rayleigh fractionation mechanism of Elderfield et al. (1996). We demonstrate that the proportion of the internal $\mathrm{Ca}$ pool used for calcification is a function of seawater $\Delta\left[\mathrm{CO}_{3}^{2-}\right]$, possibly through a direct influence on growth rate and/or the energetic cost of raising the internal vesicle $\mathrm{pH}$. Our observations for $\mathrm{Li}$ partition coefficients for several species suggest that if Rayleigh fractionation is the correct model of ion discrimination, there may be significant differences in the replenishing/flushing dynamics of the internal pool between species. Rayleigh fractionation may also control $\mathrm{Mg}$ and B incorporation, but to account for the small empirical partition coefficients either the fractionation factor from the internal pool must be much smaller than the inorganic partition coefficient and/or additional fractionation mechanisms operate. In situ sampling of the minor and trace element composition of foraminiferal vesicles will provide constraints on the $\mathrm{Mg}$ and $\mathrm{B}$ fractionation factor $(\alpha)$ and insights into the possible role of ion transport fractionation. The presence of two phases of $\mathrm{Mg}$-calcite, whose proportions reflect changes in $\Delta\left[\mathrm{CO}_{3}^{2-}\right]$, cannot be vigorously assessed because the $\mathrm{Li}$, $\mathrm{B}$ and $\mathrm{Sr}$ composition of these phases is unknown at present. However, if this mechanism is the dominant influence on empirical partition coefficients, the similarity of the relationships between $\mathrm{Li}, \mathrm{B}, \mathrm{Mg}$ and $\mathrm{Sr}$ and $\Delta\left[\mathrm{CO}_{3}^{2-}\right]$ would predict that the high-Mg calcite phase would have higher concentrations of $\mathrm{Li}, \mathrm{B}$ and $\mathrm{Sr}$ than the low-Mg calcite phase. The relevance of this biomineralisation mechanism for $O$. umbonatus can be tested by characterizing the minor and trace element composition of the two $\mathrm{Mg}$-calcite phases and comparing it to the predicted composition based on the $\mathrm{X} / \mathrm{Ca}-\Delta\left[\mathrm{CO}_{3}^{2-}\right]$ relationships presented here.

Although it is not possible to unequivocally distinguish the source of element fractionation in $O$. umbonatus, the new $\mathrm{X} / \mathrm{Ca}$ data provide testable constraints for biomineralisation models. The consistency of the O. umbonatus minor and trace element partition coefficients with several of the hypothesized models of biomineralisation in foraminifera illustrates that there is likely a mechanistic cause for the 
empirical correlation observed between $\mathrm{X} / \mathrm{Ca}$ and bottom water $\Delta\left[\mathrm{CO}_{3}^{2-}\right]$, rather than reflecting the covariation of $\Delta\left[\mathrm{CO}_{3}^{2-}\right]$ with other hydrographic parameters that influence $\mathrm{X} / \mathrm{Ca}$. This assessment provides some confidence that the core top relationships between $O$. umbonatus $\mathrm{X} / \mathrm{Ca}$ and bottom water $\Delta\left[\mathrm{CO}_{3}^{2-}\right]$ could be applied to earlier periods of Earth history.

Acknowledgements. The authors gratefully acknowledge R. Eagle and E. Khadun for assistance with sample preparation and analysis, M. Greaves and J. Day for providing technical assistance, H. Elderfield, R. Eagle, and A. Sadekov for discussion and thoughtful comments from A. Gagnon. C. F. D. was funded by a NERC studentship. A. T. gratefully acknowledges financial support by NERC, Magdalene College at the University of Cambridge, and the UCLA Division of Physical Sciences.

Edited by: H. Kitazato

\section{References}

Allen, K. A., Hönisch, B., Eggins, S. M., Yu, J., Spero, H. J., and Elderfield, H.: Controls on boron incorporation in cultured tests of the planktic foraminifer Orbulina universa, Earth Planet. Sci. Lett., 309, 291-301, doi:10.1016/j.eps1.2011.07.010, 2011.

Anand, P. and Elderfield, H.: Variability of $\mathrm{Mg} / \mathrm{Ca}$ and $\mathrm{Sr} / \mathrm{Ca}$ between and within the planktonic foraminifers Globigerina bulloides and Globorotalia truncatulinoides, Geochem. Geophys. Geosyst., 6, Q11D15, doi:10.1029/2004GC000811, 2005.

Archer, D. E.: Equatorial Pacific calcite preservation cycles: production or dissolution, Paleoceanography, 6, 561-571, 1991.

Barker, S., Greaves, M., and Elderfield, H.: A study of cleaning procedures used for foraminiferal $\mathrm{Mg} / \mathrm{Ca}$ paleothermometry, Geochem. Geophys. Geosyst., 4, 8407, doi:10.1029/2003GC000559, 2003.

Bentov, S. and Erez, J.: Novel observations on biomineralization processes in foraminifera and implications for $\mathrm{Mg} / \mathrm{Ca}$ ratio in the shells, Geology, 33, 841-844, doi:10.1130/G21800.1, 2005.

Brown, R. E., Anderson, L. D., Thomas, E., and Zachos, J. C.: A core-top calibration of $\mathrm{B} / \mathrm{Ca}$ in the benthic foraminifers Nuttallides umbonifera and Oridorsalis umbonatus: A proxy for Cenozoic bottom water carbonate saturation, Earth Planet. Sci. Lett., 310, 360-368, doi:10.1016/j.eps1.2011.08.023, 2011.

Bryan, S. P. and Marchitto, T. M.: $\mathrm{Mg} / \mathrm{Ca}-$ temperature proxy in benthic foraminifera: New calibrations from the Florida Straits and a hypothesis regarding $\mathrm{Mg} / \mathrm{Li}$, Paleoceanography, 23, PA2220, doi:10.1029/2007PA001553, 2008.

Cherniak, D. J.: Diffusion in carbonates, fluorite, sulfide minerals, and diamond (in Diffusion in minerals and melts), Rev, Mineral. Geochem., 871-897,doi:10.2138/rmg.2010.72.19, 2010.

Corliss, B. H.: Microhabitats of benthic foraminifera within deepsea sediments, Nature, 314, 435-438, doi:10.1038/314435a0, 1985.

Dawber, C. F. and Tripati, A. K.: Constraints on glaciation in the middle Eocene (46-37 Ma) from Ocean Drilling Program (ODP) Site 1209 in the tropical Pacific Ocean, Paleoceanography, 26, PA2208, doi:10.1029/2010PA002037, 2011a.
Dawber, C. F. and Tripati, A. K.: Element/Calcium ratios in middle Eocene samples of Oridorsalis umbonatus from Ocean Drilling Program Site 1209, Clim. Past Discuss., 7, 3795-3821, doi:10.5194/cpd-7-3795-2011, 2011 b.

De Nooijer, L. J., Toyofuku, T., and Kitazato, H.: Foraminifera promote calcification by elevating their intracellular $\mathrm{pH}$, Proc. Nat. Ac. Sci., 106, 15374, doi:10.1073/pnas.0904306106, 2009.

Dickson, A. G.: Thermodynamics of the dissociation of boric-acid in synthetic seawater from 273.15-k to 318.15-k, Deep-Sea Res. Part A, Oceanogr. Res. Pap. 37, 755-766, 1990.

Dickson, A. G. and Millero, F. J.: A comparison of the equilibrium constants for the dissociation of carbonic acid in seawater media, Deep-Sea Res., 34, 1733-1743, 1987.

Dickson, A. G., Sabine, C. L., and Christian, J. R.: Guide to best practices for ocean $\mathrm{CO}_{2}$ measurements, PICES Special Publication, 3, 191 pp., 2007.

Dissard, D., Nehrke, G., Reichart, G. J., and Bijma, J.: Impact of seawater $p \mathrm{CO}_{2}$ on calcification and $\mathrm{Mg} / \mathrm{Ca}$ and $\mathrm{Sr} / \mathrm{Ca}$ ratios in benthic foraminifera calcite: results from culturing experiments with Ammonia tepida, Biogeosciences, 7, 81-93, doi:10.5194/bg-7-81-2010, 2010.

Eggins, S. M., Sadekov, A., and De Deckker, P.: Modulation and daily banding of $\mathrm{Mg} / \mathrm{Ca}$ in Orbulina universa tests by symbiont photosynthesis and respiration: a complication for seawater thermometry? Earth Planet. Sci. Lett., 225, 411-419, doi:10.1016/j.eps1.2004.06.019, 2004.

Elderfield, H., Bertram, C. J., and Erez, J.: A biomineralization model for the incorporation of trace elements into foraminiferal calcium carbonate, Earth Planet. Sci. Lett., 142, 409-423, 1996.

Elderfield, H., Yu, J., Anand, P., Kiefer, T., and Nyland, B.: Calibrations for benthic foraminiferal $\mathrm{Mg} / \mathrm{Ca}$ paleothermometry and the carbonate ion hypothesis, Earth Planet. Sci. Lett., 250, 633-649, 2006.

Emerson, S. and Bender, M.: Carbon fluxes at the sediment-water interface of the deep-sea: Calcium carbonate preservation, J. Mar. Res., 39, 139-162, 1981.

Erez, J.: The Source of Ions for Biomineralization in Foraminifera and Their mplications for Paleoceanographic Proxies, Rev. Mineral. Geochem., 54, 115-149, doi:10.2113/0540115, 2003.

Erez, J., Bentov, S., Tishler, C., and Szafranek, D.: Intracellular calcium storage and the calcification mechanism of perforate foraminifera, PaleBios, 16, 30, 1994

Gabitov, R. I. and Watson, E. B.: Partitioning of strontium between calcite and fluid, Geochem. Geophys. Geosyst., 7, Q11004, doi:10.1029/2005GC001216, 2006.

Gabitov, R. I., Rollion-Bard, C., and Sadekov, A.: In situ study on $\delta 11 \mathrm{~B}$ and $\mathrm{B} / \mathrm{Ca}$ in synthetic aragonite and calcite: the effect of growth rate and temperature, Abstr. PP41A-1743, 2011 Fall Meeting, AGU, San Fransico, California, 5-9 December, 2011.

Gagnon, A. C., Adkins, J. F., Fernandez, D. P., and Robinson, L. F.: $\mathrm{Sr} / \mathrm{Ca}$ and $\mathrm{Mg} / \mathrm{Ca}$ vital effects correlated with skeletal architecture in a scleractinian deep-sea coral and the role of Rayleigh fractionation, Earth Planet. Sci. Lett., 261, 280-295, 2007.

Hall, J. M. and Chan, L. H.: Li/Ca in multiple species of benthic and planktonic foraminifera: thermocline, latitudinal, and glacial-interglacial variation, Geochim. Cosmochim. Acta, 68, 529-545, 2004.

Healey, S. L., Thunell, R. C., and Corliss, B. H.: The Mg/Catemperature relationship of benthic foraminiferal calcite: New 
core-top calibrations in the $<4{ }^{\circ} \mathrm{C}$ temperature range, Earth Planet. Sci. Lett., 272, 523-530, doi:10.1016/j.eps1.2008.05.023, 2008.

Hemming, N. G., Reeder, R. J., and Hanson, G. N.: Mineralfluid partitioning and isotopic fractionation of boron in syntheic calcium carbonate, Geochim. Cosmochim. Acta, 59, 371-379, 1995.

Hendry, K. R., Rickaby, R. E. M., Meredith, M. P., and Elderfield, H.: Controls on stable isotope and trace metal uptake in Neogloboquadrina pachyderma (sinistral) from an Antarctic sea-ice environment, Earth Planet. Sci. Lett., 278, 67-77, doi:10.1016/j.epsl.2008.11.026, 2009.

Holland, H., Holland, H., and Munoz, J.: The coprecipitation of cations with $\mathrm{CaCO}_{3}$-II. The coprecipitation of $\mathrm{Sr}+2$ with calcite between $90^{\circ}$ and $100^{\circ} \mathrm{C}$, Geochim. Cosmochim. Acta, 28, 1287-1301, doi:10.1016/0016-7037(64)90130-9, 1964.

Katz, A.: The interaction of magnesium with calcite during crystal growth at 25-90C and one atmosphere, Geochim. Cosmochim. Acta, 37, 1563-1578, 1973.

Kisakürek, B., Eisenhauer, A., Böhm, F., Garbe-Schönberg, D., and Erez, J.: Controls on shell $\mathrm{Mg} / \mathrm{Ca}$ and $\mathrm{Sr} / \mathrm{Ca}$ in cultured planktonic foraminiferan, Globigerinoides ruber (white), Earth Planet. Sci. Lett., 273, 260-269, doi:10.1016/j.epsl.2008.06.026, 2008.

Kitano, Y., Kanamori, N., and Oomori, T.: Measurements of distribution coefficients of strontium and barium between carbonate precipitate and solution - Abnormally high values of distribution coefficients measured at early stages of carbonate formation, Geochem. J., 4, 183-206, 1971.

Kunioka, D., Shirai, K., Takahata, N., Sano, Y., Toyofuku, T., and Ujiie, Y.: Microdistribution of $\mathrm{Mg} / \mathrm{Ca}, \mathrm{Sr} / \mathrm{Ca}$, and $\mathrm{Ba} / \mathrm{Ca}$ ratios in Pulleniatina obliquiloculata test by using a NanoSIMS: Implication for the vital effect mechanism, Geochem. Geophys. Geosyst., 7, Q12P20, doi:10.1029/2006GC001280, 2006.

Lea, D., Mashiotta, T., and Spero, H.: Controls on magnesium and strontium uptake in planktonic foraminifera determined by live culturing, Geochim. Cosmochim. Acta, 63, 2369-2379, 1999.

Lear, C. and Rosenthal, Y.: Benthic foraminiferal Li/Ca: Insights into Cenozoic seawater carbonate saturation state, Geology, 34, 985-988, 2006.

Lear, C., Elderfield, H., and Wilson, P.: Cenozoic deepsea temperatures and global ice volumes from $\mathrm{Mg} / \mathrm{Ca}$ in benthic foraminiferal calcite, Science, 287, 269-272, doi:10.1126/science.287.5451.269, 2000.

Lear, C., Rosenthal, Y., and Slowey, N.: Benthic foraminiferal $\mathrm{Mg} / \mathrm{Ca}$-paleothermometry: A revised core-top calibration, Geochim. Cosmochim. Acta, 66, 3375-3387, 2002.

Lear, C., Elderfield, H., and Wilson, P.: A Cenozoic seawater $\mathrm{Sr} / \mathrm{Ca}$ record from benthic foraminiferal calcite and its application in determining global weathering fluxes, Earth Planet. Sci. Lett., 208, 69-84, 2003.

Lear, C. H., Mawbey, E. M., and Rosenthal, Y.: Cenozoic benthic foraminiferal $\mathrm{Mg} / \mathrm{Ca}$ and $\mathrm{Li} / \mathrm{Ca}$ records: Toward unlocking temperatures and saturation states, Paleoceanography, 25, PA4215, doi:10.1029/2009PA001880, 2010.

Lorens, R. B.: A study of biological and physical controls on the trace metal content of calcite and aragonite, Ph.D. dissertation. Univ. of Rhode Island, 1978.

Lorens, R. B.: Sr, Cd, Mn and Co distribution coefficients in calcite as a function of calcite precipitation rate, Geochim. Cosmochim.
Acta, 45, 553-561, 1981.

Marchitto, T. M., Oppo, D. W., and Curry, W. B.: Paired benthic foraminiferal $\mathrm{Cd} / \mathrm{Ca}$ and $\mathrm{Zn} / \mathrm{Ca}$ evidence for a greatly increased presence of Southern Ocean Water in the glacial North Atlantic, Paleoceanography, 17, 1038, doi:10.1029/2000PA000598, 2002.

Marchitto, T. M., Bryan, S. P., Curry, W. B., and McCorkle, D. C.: $\mathrm{Mg} / \mathrm{Ca}$ temperature calibration for the benthic foraminifer Cibicidoides pachyderma, Paleoceanography, 22, PA1203, doi:10.1029/2006PA001287, 2007.

Marriott, C. S., Henderson, G. M., Crompton, R., Staubwasser, M., and Shaw, S.: Effect of mineralogy, salinity, and temperature on $\mathrm{Li} / \mathrm{Ca}$ and $\mathrm{Li}$ isotope composition of calcium carbonate, Chem. Geol., 212, 5-15, 2004.

Martin, W. and Sayles, F.: CaCO3 dissolution in sediments of the Ceara Rise, western equatorial Atlantic, Geochim. Cosmochim. Acta, 60, 243-263, doi:10.1016/0016-7037(95)00383-5, 1996.

Mehrbach, C., Culberso, C. H., Hawley, J. E., and Pytkowic, R. M.: Measurement of apparent dissociation-constants of carbonicacid in seawater at atmospheric-pressure, Limnol. Oceanogr., 18, 897-907, 1973.

Morse, J. and Bender, M.: Partition coefficients in calcite: Examination of factors influencing the validity of experimental results and their application to natural systems, Chem. Geol., 82, 265-277, 1990.

Morse, J. W. and Mackenzie, F. T.: Geochemistry of Sedimentary Carbonates, Develop. Sediment., 48, 707 pp., 1990.

Mucci, A. and Morse, J. W.: The incorporation of $\mathrm{Mg} 2$ and $\mathrm{Sr} 2$ into calcite overgrowths: Influences of growth rate and solution composition, Geochim. Cosmochim. Acta, 47, 217-233, 1983.

Nehrke, G., Reichart, G. J., Van Cappellen, P., Meile, C., and Bijma, J.: Dependence of calcite growth rate and $\mathrm{Sr}$ partitioning on solution stoichiometry: Non-Kossel crystal growth, Geochim. Cosmochim. Acta, 71, 2240-2249, 2007.

Okumura, M. and Kitano, Y.: Coprecipitation of alkali metal ions with calcium carbonate, Geochim. Cosmochim. Acta, 50, 49-58, 1986.

Pingitore Jr., N. E. and Eastman, M. P.: The coprecipitation of Sr2+ with calcite at $25^{\circ} \mathrm{C}$ and 1 atm, Geochimica et Cosmochimica Acta, 50, 2195-2203, doi:10.1016/0016-7037(86)90074-8, 1986.

Rae, J. W. B., Foster, G. L., Schmidt, D. N., and Elliott, T.: Boron isotopes and $\mathrm{B} / \mathrm{Ca}$ in benthic foraminifera: Proxies for the deep ocean carbonate system, Earth Planet. Sci. Lett., 302, 403-413, doi:10.1016/j.eps1.2010.12.034, 2011.

Rathmann, S. and Kuhnert, H.: Carbonate ion effect on $\mathrm{Mg} / \mathrm{Ca}$, $\mathrm{Sr} / \mathrm{Ca}$ and stable isotopes on the benthic foraminifera Oridorsalis umbonatus off Namibia, Mar. Micropaleo., 66, 120-133, 2008.

Rathmann, S., Hess, S., Kuhnert, H., and Mulitza, S.: Mg/Ca ratios of the benthic foraminifera Oridorsalis umbonatus obtained by laser ablation from core top sediments: Relationship to bottom water temperature, Geochem. Geophys. Geosyst., 5, Q12013, doi:10.1029/2004GC000808, 2004.

Rickaby, R. E. M., Elderfield, H., Roberts, N., Hillenbrand, C.-D., and Mackensen, A.: Evidence for elevated alkalinity in the glacial Southern Ocean, Paleoceanography, 25, $15 \mathrm{pp}$., doi:201010.1029/2009PA001762, 2010.

Rimstidt, J. D., Balog, A., and Webb, J.: Distribution of trace elements between carbonate minerals and aqueous solutions, Geochim. Cosmochim. Acta, 62, 1851-1863, 1998. 
Rosenthal, Y., Boyle, E. A., and Slowey, N.: Temperature control on the incorporation of magnesium, strontium, fluorine, and cadmium into benthic foraminiferal shells from Little Bahama Bank: Prospects for thermocline paleoceanography, Geochim. Cosmochim. Acta, 61, 3633-3643, 1997.

Rosenthal, Y., Lear, C. H., Oppo, D. W., and Linsley, B. K.: Temperature and carbonate ion effects on $\mathrm{Mg} / \mathrm{Ca}$ and $\mathrm{Sr} / \mathrm{Ca}$ ratios in benthic foraminifera: Aragonitic species Hoeglundina elegans, Paleoceanography, 21, PA1007, doi:10.1029/2005PA001158, 2006.

Russell, A. D., Hönisch, B., Spero, H. J., and Lea, D. W.: Effects of seawater carbonate ion concentration and temperature on shell $\mathrm{U}$, $\mathrm{Mg}$, and $\mathrm{Sr}$ in cultured planktonic foraminifera, Geochim. Cosmochim. Acta, 68, 4347-4361, 2004.

Sabine, C. L. and Tanhua, T.: Estimation of Anthropogenic $\mathrm{CO}_{2}$ Inventories in the Ocean, Annu. Rev. Marine. Sci., 2, 175-198, doi:10.1146/annurev-marine-120308-080947, 2010.

Sabine, C. L., Feely, R. A., Gruber, N., Key, R. M., Lee, K., Bullister, J. L., Wanninkhof, R., Wong, C. S., Wallace, D. W. R., Tilbrook, B., Millero, F. J., Peng, T. H., Kozyr, A., Ono, T., and Rios, A. F.: The Oceanic Sink for Anthropogenic $\mathrm{CO}_{2}$, Science, 305, 367-371, doi:10.1126/science.1097403, 2004.

Sadekov, A. Y., Eggins, S. M., and De Deckker, P.: Characterization of $\mathrm{Mg} / \mathrm{Ca}$ distributions in planktonic foraminifera species by electron microprobe mapping, Geochem. Geophys. Geosyst., 6, Q12P06, doi:10.1029/2005GC000973, 2005.

Szafranek, D. and Erez, J.: Chemistry of Mg, SO42-, Sr, $\mathrm{Na}$ and $\mathrm{Cl}$ in live foraminifera shells, Abstract. Int. Symp. On Biomineralization, Monaco, Biomineralization, 93, 1993.

Tang, J., Köhler, S. J., and Dietzel, M.: Sr2+/Ca2+ and 44Ca/40Ca fractionation during inorganic calcite formation: I. Sr incorporation, Geochim. Cosmochim. Acta, 72, 3718-3732, 2008.

Tripati, A. K. and Elderfield, H.: Deep-sea Temperature and Circulation Changes at the Paleocene-Eocene Thermal Maximum, Science, 308, 1894-1898, doi:10.1126/science.1109202, 2005.
Tripati, A. K., Backman, J., Elderfield, H., and Ferretti, P.: Eocene Bipolar Glaciation Associated with Global Carbon Cycle Changes, Nature, 436, 341-346, doi:10.1038/nature03874, 2005.

Watson, E. B.: A conceptual model for near-surface kinetic controls on the trace-element and stable isotope composition of abiogenic calcite crystals, Geochim. Cosmochim. Acta, 68, 14731488, 2004.

Watson, E. B. and Liang, Y.: A simple model for sector zoning in slowly grown crystals: Implications for growth rate and lattice diffusion, with emphasis on accessory minerals in crustal rocks, Am. Mineral., 80, 1179-1187, 1995.

Waugh, D. W., Hall, T. M., McNeil, B. I., Key, R. M., and Matear, R.: Anthropogenic $\mathrm{CO}_{2}$ in the oceans estimated using transittime distributions, Tellus B, 58, 376-389, 2006.

$\mathrm{Yu}$, J. and Elderfield, H.: Benthic foraminiferal B/Ca ratios reflect deep water carbonate saturation state, Earth Planet. Sci. Lett., 258, 73-86, 2007.

$\mathrm{Yu}$, J. and Elderfield, $\mathrm{H} .: \mathrm{Mg} / \mathrm{Ca}$ in the benthic foraminifera Cibicidoides wuellerstorfi and Cibicidoides mundulus: Temperature versus carbonate ion saturation, Earth Planet. Sci. Lett., 276, 129-139, 2008.

Yu, J., Day, J., Greaves, M., and Elderfield, H.: Determination of multiple element/calcium ratios in foraminiferal calcite by quadrupole ICP-MS, Geochem. Geophys. Geosyst., 6, Q08P01, doi:10.1029/2005GC000964, 2005.

Yu, J., Elderfield, H., and Hönisch, B.: B/Ca in planktonic foraminifera as a proxy for surface seawater $\mathrm{pH}$, Paleoceanography, 22, doi:10.1029/2006PA001347, 2007.

Zeebe, R. E. and Sanyal, A.: Comparison of two potential strategies of planktonic foraminifera for house building: $\mathrm{Mg} 2+$ or $\mathrm{H}+$ removal?, Geochim. Cosmochim. Acta, 66, 1159-1169, doi:16/S00167037(01)00852-3, 2002. 